\title{
A Chiral Macrocyclic Oligothiophene with Broken Conjugation - Rapid Racemization through Internal Rotation
}

\author{
Kevin J. Weiland, ${ }^{a}$ Nathalia Münch, ${ }^{a}$ Wanja Gschwind, ${ }^{a}$ Daniel Häussinger, ${ }^{a}$ and Marcel Mayor *a,a,c \\ a Department of Chemistry, University of Basel, St. Johanns-Ring 19, 4056 Basel, Switzerland, marcel.mayor@unibas.ch \\ ${ }^{b}$ Institute for Nanotechnology (INT), Karlsruhe Institute of Technology (KIT), P. O. Box 3640, 76021 Karlsruhe, Germany \\ 'Lehn Institute of Functional Materials, School of Chemistry, Sun Yat-Sen University, Guangzhou 510275, China
}

Dedication to Prof. François Diederich on the occasion of his retirement celebration.

\begin{abstract}
A macrocyclic oligothiophene with an integrated pseudo-para substituted [2.2]paracyclophane has been achieved. The synthetic sequence relies on alternating steps of halogenation- and Suzuki-coupling conditions. By employing a modified Eglinton reaction under high dilution conditions, the macrocycle is closed and the obtained diacetylene is efficiently transferred to the corresponding thiophene. The molecule is fully characterized and its dynamic racemization is analysed by variable temperature NMR experiments. The racemization barrier hints with $38 \mathrm{~kJ} / \mathrm{mol}$ at rapid enantiomerization at room temperature by Mislow's "Euclidian rubber glove" enantiomerization process. Macrocycle formation results in redshifted absorption and emission spectra, hinting at increased conjugation through the oligothiophene versus the trough space conjugation through the [2.2]paracyclophane.
\end{abstract}

Keywords: Cyclophanes $\bullet$ Oligothiophenes $\bullet$ Macrocycles $\bullet$ Helical Chirality

\section{Introduction}

The ongoing miniaturization of electronic components approaches the nanometer scale, and novel concepts to fabricate objects in this range are a topic of high interest. One of the fabrication principles can be the bottom-up synthesis of molecules, profiting from the impressive achievements reported in the synthetic and macromolecular community. This assembly of tailor-made macromolecules from small reactive building blocks is approaching the nanoscale form the opposed direction than the scaling down of bulk materials in conventional inorganic silicon-based technology ${ }^{[1]}$ and promising new research directions develop at the interface between both approaches.

Over the past decades, conjugated macrocycles have attracted high interest due to both, their structural integrity offering welldefined shapes and diameters, and their role as model compounds for infinitely conjugated $\pi$-systems. ${ }^{[2,3]}$ Furthermore their physical and chemical features like their optical, electrochemical, and encapsulation properties moved into the focus of interest. ${ }^{[4-7]} A$ synthetic milestone in the field of conjugated aromatic compounds was the synthesis and investigation of Kekulene by the young François Diederich in the labs of Heinz Staab. ${ }^{[8,9]}$

Various molecular motifs have been reported as subunits of conjugated macrocyclic compounds, like e.g. pyridines, benzenes, acetylenes as well as five-membered aromatic heterocycles, like furans and thiophenes. ${ }^{[10,11]}$ We reported the assembly and investigation of a variety of macrocycles consisting of aromatic subunits in the past, among others structures comprising functional subunits like redox chromophores ${ }^{[12,13]}$ or optically addressable azo-benzenes, ${ }^{[14]}$ macrocycles designed as single molecule switches ${ }^{[15-17]}$ or with pronounced $\pi$-stacking features, ${ }^{[18,19]}$ and giant macrocycles as model compounds for persistent ring currents. ${ }^{[20]}$ More recently, our focus moved to axial chiral systems like bicyclic "Geländer"-type structures ${ }^{[2]}$ or the macrocyclization of the ligands assembled in a $\mathrm{M}(\mathrm{II})$ terpyridine complex resulting in a helical macrocycle with an arrangement resembling a propeller. ${ }^{[22]}$
Cyclo[n]thiophenes are an interesting class of conjugated macrocycles; they are model compounds for polythiophenes, with well-defined self-assembling and electronic features. ${ }^{[23]}$ Initially, the synthesis of macrocyclic oligothiophenes was performed by reacting on both sides ethynyl-terminated ter- and quinquethiophenes under oxidative acetylene coupling conditions in the presence of a copper catalyst. ${ }^{[3]}$ The resulting diethynyl linkers in the macrocycles were converted to thiophenes with sodium sulfide to form the corresponding cyclo[n]thiophenes. In this way, a library of macrocycles was obtained, where the smallest member of the series contained twelve thiophenes. In a later approach, strained oligothiophenic macrocycles were assembled, where only one diacetylene was formed oxidatively. ${ }^{[2]}$ Bäuerle and coworkers also reported on catenanes,

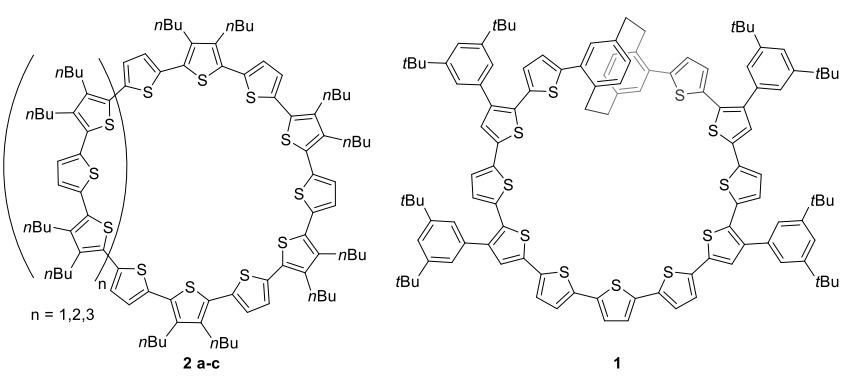

Figure 1. Series of oligothiophene macrocycles 2 a-c (left side) developed by Bäuerle et al. as basis for the design of the target structure 1 (right side) The eleven thiophene subunits of the macrocycle are separated by a step due to the pseudo-para substituted PC subunit (top) which disturbs the conjugation. The four peripheral bis-3,5-(tert-butyl)phenyl substituents provide the solubility required for wet chemical processing.

where the synthesis of the target structure was achieved through complexation of platinum followed by reductive elimination to obtain the corresponding catenanes, comprising the diethynyl link in their oligothiophene macrocycles. ${ }^{[25]}$ 
The here presented structure is inspired by a split-ring resonator (SRR). This is the smallest possible realization of a circuit comprising a coil and a capacitor and thus displays interesting interactions with electromagnetic fields of suitable wavelength. ${ }^{[26]}$ As an example, a negative refractive index at microwave frequencies was reported for a large array of equally micrometer sized metallic SRRs. ${ }^{[27,28]}$

The design of molecule 1 (Fig. 1) combines the conjugated periphery of an oligothiophene macrocycle with the conjugation altering pseudo-para [2.2] paracyclophane ( $\mathrm{PC})$. Using again the inspiring picture of a SRR, the macrocycle consisting of 2,5-interlinked thiophenes represent the "ring", while the PC acts as the "split". A particular appealing feature from the molecular design perspective is the helical chirality introduced by the step-like PC in the macrocycle, which might result in intriguing structural and chiroptical properties. ${ }^{[29]}$

The step in the macrocycle is realized due to the 3D-structure of pseudo-para [2.2] paracyclophane (PC). ${ }^{[30]}$ It has attracted considerable attention due to the face-to-face orientation of its benzene rings, which are considerably closer than twice their individual van-derWaals radii (typical ring distance: $3.09 \AA$ ), resulting in unusual optical, electronical and through-space charge-delocalization properties. ${ }^{[31-34]}$ For example the comparison of annulene-PC hybrids with their benzannulene analogues displays typically a bathochromic shift in their absorption spectra, indicating an electronic conjugation throughout the PC building block. ${ }^{[35]}$ Also, electrochemical investigations of dithienyl-substituted PC point at electronic coupling, as the oxidation wave is separated documenting the interdependence of both redox chromophores. ${ }^{[34,36]}$ Self assembled molecular rods comprising a central PC unit displayed very comparable electronic transport features compared with their benzene analogues, such that the limited control over the number of molecules in the crossed-wire junctions did not allow to trace the origin of the observed subtle variations. ${ }^{[32]}$ Very recent single molecule experiments with molecular rods comprising a central PC subunit in a mechanically controlled break junction experiment even displayed mechanically triggered quantum interference in the junctions transport behavior. ${ }^{[37]}$

Symmetrical disubstitution of PC leads to four different regionisomers. ${ }^{[38]}$ Pseudo-para and geminal disubstitution leads to derivateives that are achiral due to internal symmetry elements. ${ }^{[39]}$ However, pseudo-ortho and meta disubstitution leads to chiral products, separation of enantiomers of PCs with different substitution pattern have been accomplished. ${ }^{[40]}$ Notably, pseudo-ortho disubstituted PC derivatives were incorporated in chiral thiophene-PC macrocycles, which showed pronounced chiroptical behavior. ${ }^{[41]}$

Here we report a novel approach making the pseudo-para disubstituted PC chiral by integrating it in the macrocyclic structure $\mathbf{1}$. In 1 the macrocycle is complemented by eleven 2,5-diyl-thiophene subunits, which are introduced pairwise in a sequential synthetic strategy at both ends of the open oligomer in order to identify the number of thiophene subunits required for a successful macrocyclization. In addition, four bis-3,5-(tert-butyl)phenyl substituents provide the solubility in organic solvents required to enable wet chemical processing of both, the precursors and the target structure. The unique integration of the PC substitution pattern in the macrocyclic structure 1 leads, to the best of our knowledge, to the first chiral pseudo-para symmetrically disubstituted PC, as the introduction of the macrocycle leads to decreased symmetry. Interesting is the enantiomerization of $\mathbf{1}$, which due to its 3D PC building block follows Mislow's "Euclidean rubber glove" mechanism. ${ }^{[42,43]}$ In other words, the molecule becomes its mirror image by rotations around single bonds without ever adapting a flat achiral conformation. The enantiomerization mechanism thus resembles the inversion of the chirality of a rubber glove, which is achieved by the complex movement of turning the glove inside out.

In this paper the stepwise assembly of the macrocycle $\mathbf{1}$ is reported together with its full characterization. The molecular dynamics of $\mathbf{1}$ are investigated by variable temperature NMR (VTNMR) experiments shining light on its unique racemization behavior. The extent of electronic conjugation through macrocycle $\mathbf{1}$ and its precursors is qualitatively investigated by UV-Vis absorption and emission spectroscopy.

\section{Results and Discussion}

The synthesis of a complex structure as macrocycle 1 requires repetitive synthetic steps; mainly alternating halogenation and $\mathrm{Pd}$ catalyzed carbon-carbon coupling reactions.

The linear and sequential synthetic strategy for macrocycle $\mathbf{1}$ involves a late stage macrocyclization and formation of a thiophene from the
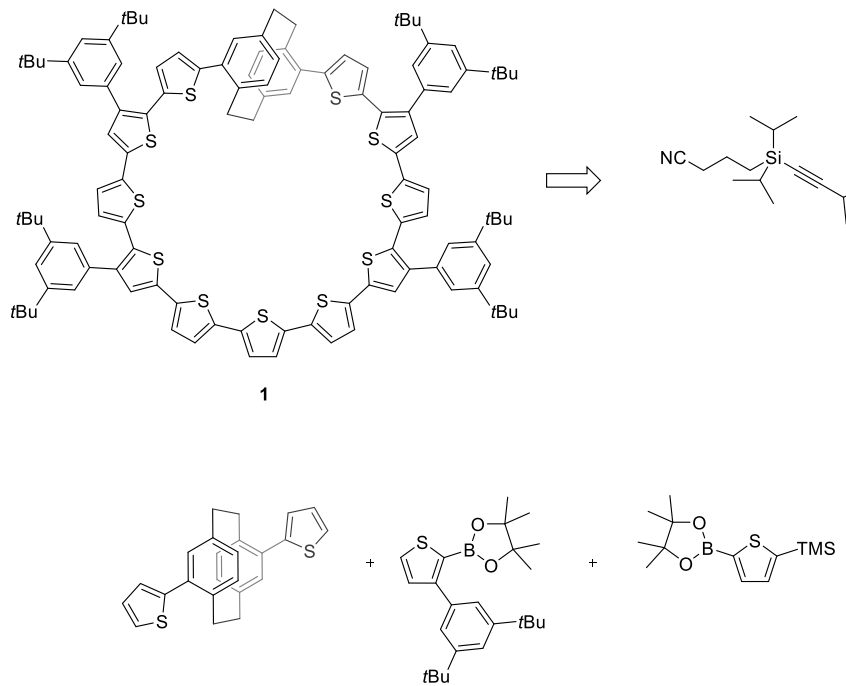

6<smiles>CC=CC(C)C</smiles>
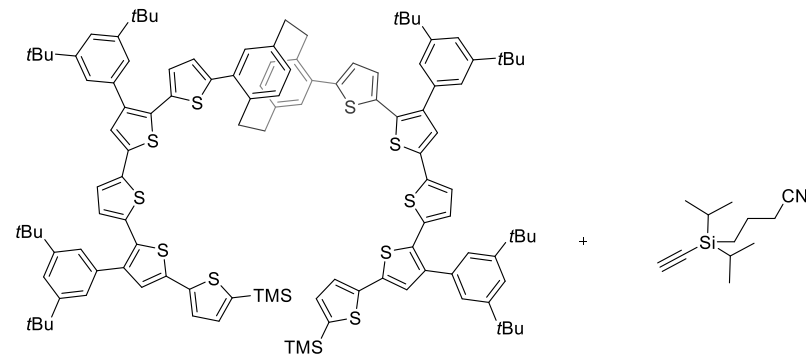

Scheme 1. Synthetic strategy for the assembly of racemic macrocycle 1. 


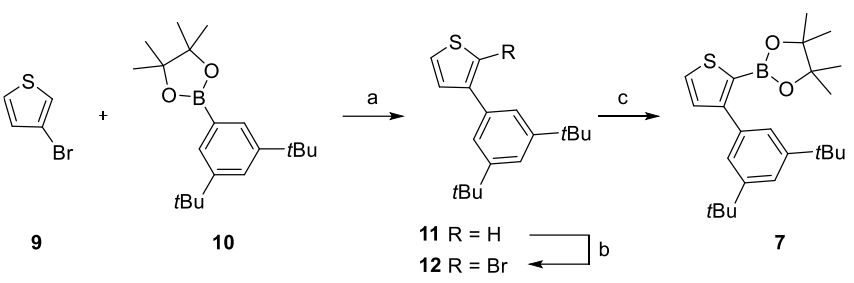

Scheme 2. Synthesis of building block 7. Reagents and conditions: (a) $\mathrm{Pd}\left(\mathrm{PPh}_{3}\right)_{4}, \mathrm{Na}_{2} \mathrm{CO}_{3}, \mathrm{DMF}, \mathrm{H}_{2} \mathrm{O}, 120^{\circ} \mathrm{C}, 2 \mathrm{~h}, 88 \%$ (b) $\mathrm{NBS}, \mathrm{CHCl}_{3}, \mathrm{AcOH}$, $40{ }^{\circ} \mathrm{C}, 1 \mathrm{~h}, 77 \%$. (c) $n$-BuLi, 2 -isopropoxy-4,4,5,5-tetramethyl-1,3,2-dioxaborolane, THF, $-78{ }^{\circ} \mathrm{C}$ to room temp., $20 \mathrm{~h}, 90 \%$.

corresponding diacetylene, based on the linear protected intermediate 3. Precedence for this strategy exists, as the cyclization of alkyne substituted oligothiophenes under oxidative acetylene coupling conditions $^{[44]}$ was employed by Bäuerle et al. for the synthesis of phenanthroline containing cyclic oligothiophenes of similar ring diameters. ${ }^{[24]}$ Based on this concept, chiral carbon-rich macrocycles were also obtained in the labs of François Diederich, who produced alleno-acetylenic macrocycles with outstanding chiroptical properties. ${ }^{[45,46]}$ The open-ring intermediate $\mathbf{3}$ is divided into two building blocks $\mathbf{4}$ and $\mathbf{5}$ which can be coupled in a Sonogashira reaction. This linear synthetic strategy allows for a step-by-step buildup of structure 4 through a series of halogenation and Suzuki coupling reactions without the need of excessive protecting-group strategies. Subunit $\mathbf{4}$ was assembled from highly functionalized building blocks 6, 7 and 8 in a repetitive halogenation, $\mathrm{Pd}$-catalyzed coupling chemistry sequence. Building block $\mathbf{7}$ and $\mathbf{8}$ were introduced to achieve reasonable solubility for all relevant intermediates during the course of the synthesis. While building blocks $\mathbf{6}$ and $\mathbf{8}$ are already literature-known, a strategy to form $\mathbf{7}$ had to be developed. ${ }^{[36,47]}$

The synthesis of building block $\mathbf{7}$, that is introduced to increase the solubility, started from commercially available 3-bromothiophene (9) and literature-known 2-(3,5-di-tert-butylphenyl)-4,4,5,5-tetramethyl-1,3,2-dioxaborolane (10). ${ }^{[48]}$

The Suzuki coupling of both compounds afforded $\mathbf{1 1}$ in $88 \%$ yield and multigram amounts of $\mathbf{1 1}$ could be isolated after purification by silica gel chromatography. Next, 11 was reacted with one equivalent of $N$ bromosuccinimide (NBS) to selectively afford 12. Excess of NBS lead to bromination also in the 5-position of the thiophene. Compound $\mathbf{1 2}$ was, after isolation by column chromatography (CC) in $77 \%$ yield, reacted with $n$-butyllithium ( $n$-BuLi) and 2-isopropoxy-4,4,5,5tetramethyl-1,3,2-dioxaborolane to yield 7. During the course of the lithiation it is crucial that the temperature is kept at $-78^{\circ} \mathrm{C}$, as at higher temperatures, deprotonation of $\mathbf{1 2}$ at the 5-position was observed, leading to the corresponding 2-bromo-5-pinacolboronato thiophene after work up. After addition of 2-isopropoxy-4,4,5,5-tetramethyl1,3,2-dioxaborolane and aqueous workup, 7 was isolated without purification in $90 \%$ yield as a yellow solid.

Having solubilizing building block $\mathbf{7}$ in hand, our focus moved towards the assembly of precursor $\mathbf{6}$. While its synthesis is already literature known, we aimed to develop a higher yielding procedure than the one published previously. Collard et al. reported a procedure relying on a Stille coupling which was efficient yet difficult to purify. ${ }^{[36]}$ More recently, a procedure developed by Martin et al. was reported which utilized Suzuki coupling conditions, however working with 5alkyl-thiophene boronic acids. ${ }^{[34]}$ Therefore, a procedure utilizing Kumada reaction conditions as developed by Rozenberg et al. was adapted. ${ }^{[49]}$ Commercially available 2 -thienyl magnesium bromide (13) was added dropwise to a suspension of pseudo-para-dibromo-PC (14) and $\mathrm{Pd}(\mathrm{dppf}) \mathrm{Cl}_{2}$ in tetrahydrofuran (THF). After heating to $60^{\circ} \mathrm{C}$ for two hours, building block 6 started to precipitate from the reaction mixture. Following aqueous workup and removal of the solvent, $\mathbf{6}$ could be isolated by washing the crude product with cyclohexane and cooled dichloromethane. Compound $\mathbf{6}$ was isolated in a yield of $87 \%$ as a white solid.

Subsequently, 6 was dibrominated with NBS in dimethylformamide (DMF), and after aqueous workup and filtration through a plug of celite, $\mathbf{1 5}$ was obtained as a white solid. $\mathbf{1 5}$ could only be dissolved in substantial amounts of toluene after heating the suspension to $60{ }^{\circ} \mathrm{C}$. Thus, compounds $\mathbf{1 5}$ and $\mathbf{7}$ were reacted in a Suzuki reaction with Pd-PEPPSI-IPr ${ }^{\mathrm{TM}}$ (PEPPSI: pyridine-enhanced precatalyst preparation stabilization and initiation, IPr: isopropyl) and $\mathrm{K}_{2} \mathrm{CO}_{3}$ in methanol $(\mathrm{MeOH})$ and toluene in a procedure adapted from Nilsson et. al. ${ }^{[50]}$ The

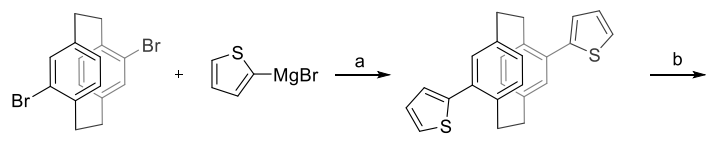

14

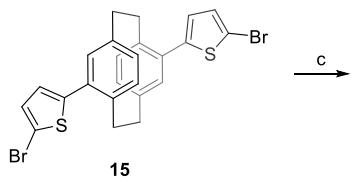

15
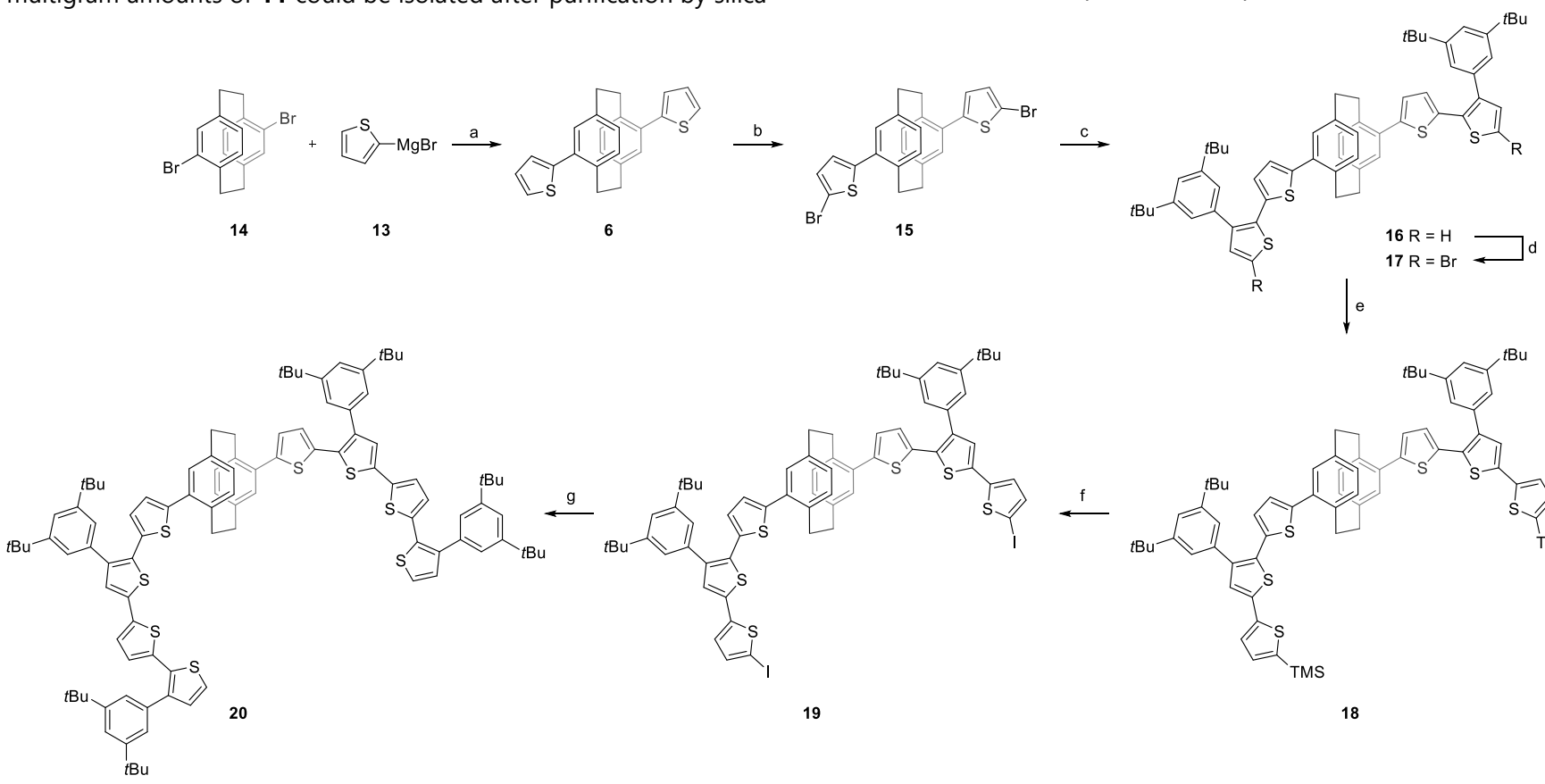

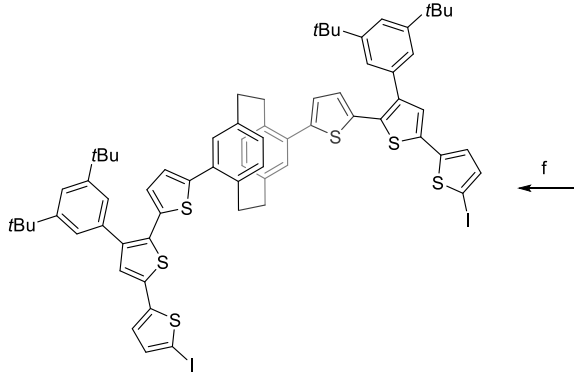

19

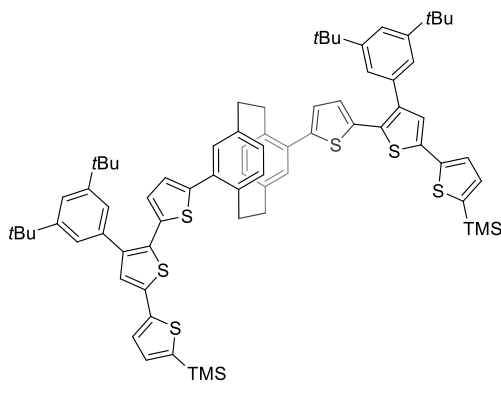

18

Scheme 3. Synthesis of fragment 20. Reagents and conditions: (a) $\mathrm{Pd}(\mathrm{dppf}) \mathrm{Cl}_{2,} \mathrm{THF}, 60{ }^{\circ} \mathrm{C}, 2 \mathrm{~h}, 87 \%$. (b) $\mathrm{NBS}, \mathrm{CHCl}_{3}, \mathrm{DMF}$, room temp., $20 \mathrm{~h}, 91 \%$. (c) 7, PdPEPPSI-IPr ${ }^{\mathrm{TM}}, \mathrm{K}_{2} \mathrm{CO}_{3}$, toluene, $\mathrm{MeOH}, 70{ }^{\circ} \mathrm{C}, 15 \mathrm{~min}, 95 \%$. (d) NBS, DMF, room temp., $20 \mathrm{~h}, 92 \%$. (e) 8, Pd-PEPPSI-IPr ${ }^{\mathrm{TM}}, \mathrm{K}_{2} \mathrm{CO}_{3}$, toluene, $\mathrm{MeOH}, 70{ }^{\circ} \mathrm{C}, 20 \mathrm{~min}$ $82 \%$. (f) $\mathrm{NIS}, \mathrm{CHCl}_{3}, \mathrm{AcOH}$, room temp., $1.5 \mathrm{~h}, 99 \%$. (g) 7, Pd-PEPPSI-IPr ${ }^{\mathrm{TM}}, \mathrm{K}_{2} \mathrm{CO}_{3}$, toluene, $\mathrm{MeOH}, 70{ }^{\circ} \mathrm{C}, 30 \mathrm{~min}, 83 \%$. 
reaction proceeded over the course of 15 minutes and $\mathbf{1 6}$ was obtained after CC in excellent yield as an off-white solid. To elongate the chain of thiophenes, $\mathbf{1 6}$ was brominated with NBS in DMF under exclusion of light. Aqueous work up and CC provided $\mathbf{1 7}$ as a yellow solid in $92 \%$ yield. Initial attempts to react $\mathbf{1 7}$ with thienyl boronic acid led to the hexathiophenic building block of very limited solubility that prevented its separation from the byproducts of the synthesis. Therefore, 17 was reacted in a Pd-PEPPSI-IPrTM catalyzed Suzuki reaction with trimethyl(5-(4,4,5,5-tetramethyl-1,3,2-dioxaborolan-2yl)thien-2-yl)silane (8) to ensure improved solubility due to the presence of TMS groups, that can be easily transferred to an iodine with $\mathrm{N}$-iodosuccinimide (NIS). ${ }^{[4]}$

After reacting $\mathbf{1 7}$ and $\mathbf{8}$ in a Pd-PEPPSI-IPr ${ }^{\top \mathrm{M}}$ catalyzed Suzuki reaction for 20 minutes, $\mathbf{1 8}$ could be isolated after aqueous workup and CC as a yellow amorphous solid. Next, $\mathbf{1 8}$ was readily interconverted to compound $\mathbf{1 9}$ by dissolving it in a 1:1 mixture of chloroform and acetic acid and treatment with NIS. During the reaction, compound 19 precipitated from the solution, but was soluble enough to be purified by CC and was isolated in quantitative yield as a yellow wax. Subsequently, 19 was reacted with building block 7 with PdPEPPSI-IPr ${ }^{\mathrm{TM}}$ and $\mathrm{K}_{2} \mathrm{CO}_{3}$ in toluene and $\mathrm{MeOH}$. After a reaction time of 30 minutes, followed by aqueous work up, 20 was isolated in good yield of $83 \%$ after $\mathrm{CC}$ as a yellow amorphous solid.

Compound $\mathbf{2 0}$ was dibrominated with NBS in $\mathrm{CHCl}_{3}$ under the exclusion of light. After reacting the mixture for 20 hours, aqueous workup and CC lead to compound $\mathbf{2 1}$ in excellent yield as a yellow amorphous solid. Subsequently, $\mathbf{2 1}$ was reacted with building block $\mathbf{8}$ under the established Suzuki coupling conditions. Chromatography on silica gel and automated gel permeation chromatography (GPC) lead to the isolation of $\mathbf{4}$ in $\mathbf{7 2} \%$ yield. Unfortunately, all attempts to convert the TMS functionality of $\mathbf{4}$ to the corresponding dibromide or -iodide lead to a complex product mixture, which according to their MALDIToF MS analyses also contained mono- and trihalogenated species besides the desired material. Attempts to isolate the desired compound from those mixtures, either by silica gel chromatography or GPC were unsuccessful. Therefore, the mixture of bromides was directy reacted with CPDIPS acetylene in a Sonogashira reaction. The use of the polar protecting group introduced by Höger et al. lead to facile isolation of the desired protected diyne $\mathbf{3}$ by silica gel chromatography in toluene in $63 \%$ yield over two subsequent steps. ${ }^{[51]}$ Deprotection of $\mathbf{3}$ to diyne $\mathbf{2 2}$ with tetrabutylammonium fluoride in THF proceeded in excellent yield.

The macrocyclization of $\mathbf{2 2}$ to $\mathbf{2 3}$ was achieved through a modified Eglinton coupling as published by Scott et al ${ }^{[52]}$ To facilitate selective formation of $\mathbf{2 3}$, a $0.55 \mathrm{~mm}$ solution of $\mathbf{2 2}$ in pyridine was added by a syringe pump over the course of 48 hours to a solution of 15 equivalents $\mathrm{CuCl}$ and 21 equivalents $\mathrm{Cu}(\mathrm{OAc})_{2}$ in $60 \mathrm{~mL}$ of pyridine. After aqueous workup, CC and size exclusion chromatography (BioBeads, SX-3) in toluene, the key intermediate $\mathbf{2 3}$ was isolated as a red amorphous solid in $33 \%$ yield. We also observed the twofold closed cyclic dimer of 22, which was removed easily by size exclusion chromatography. It is noteworthy that the macrocyclization of a similar molecule with eight thiophenes instead of ten exclusively resulted in the formation of its twofold closed dimer. The final cyclization step to form the target compound $\mathbf{1}$ was performed using a procedure of Bäuerle et al., where $\mathbf{2 3}$ was reacted with $\mathrm{Na}_{2} \mathrm{~S} \cdot 9 \mathrm{H}_{2} \mathrm{O}$ in a 1:1 mixture of DMF and 2-methoxyethanol. ${ }^{[25]}$ To our delight, MALDI-TOF analysis of the reaction mixture after 1.5 hours showed only the mass of the target compound 1. After acidic workup to remove excess reagent and solvent, and subsequent purification by CC, target compound $\mathbf{1}$ was isolated as a red amorphous solid in quantitative yield.

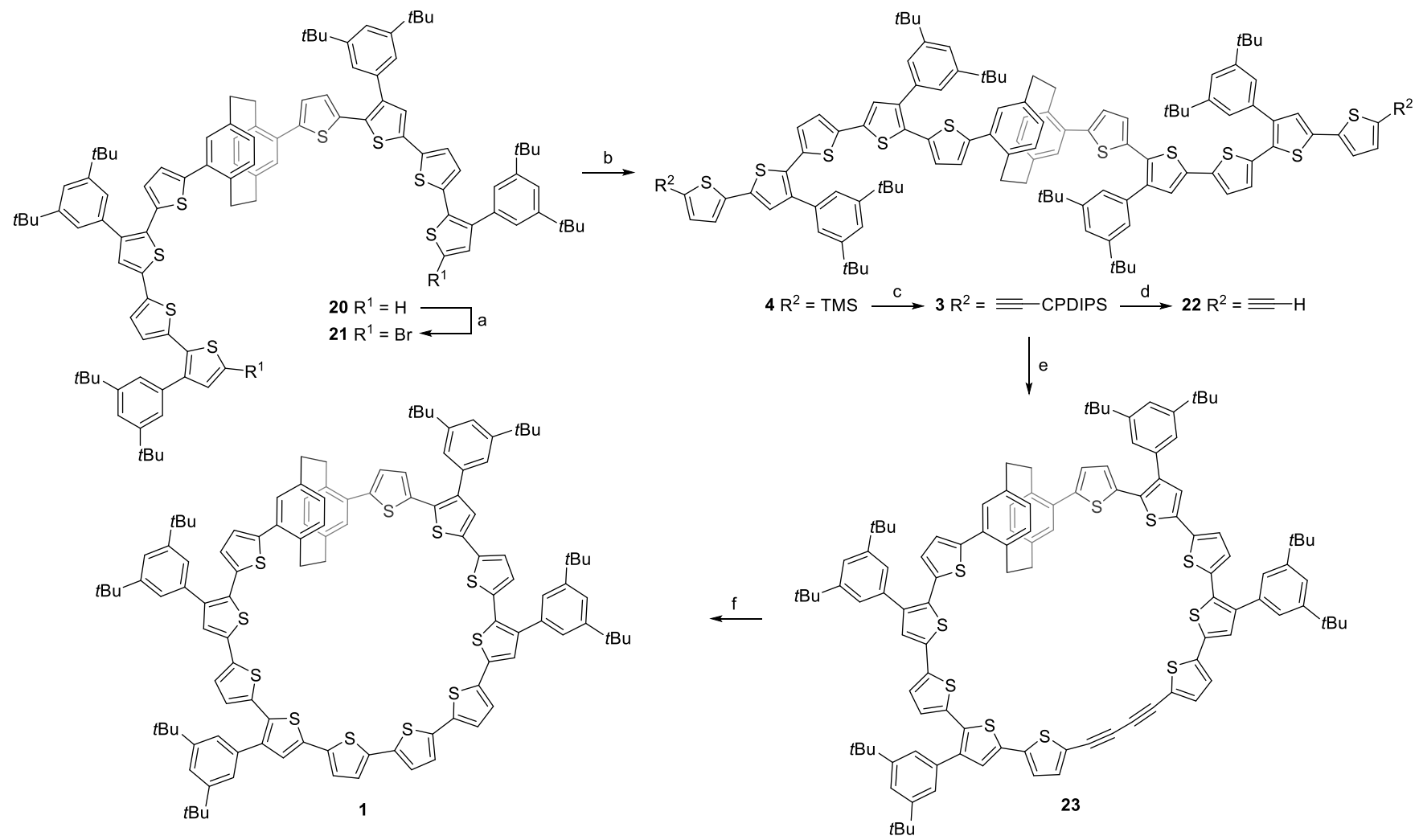

Scheme 4. Synthesis of target molecule 1. Reagents and conditions: (a) NBS, $\mathrm{CHCl}_{3}$, room temp., $20 \mathrm{~h}$, 90\%. (b) 8, $\mathrm{Pd}-\mathrm{PEPPSI}_{\mathrm{IPr}} \mathrm{TM}^{\mathrm{M}}, \mathrm{K}_{2} \mathrm{CO}_{3}$, toluene, $\mathrm{MeOH}$, $70{ }^{\circ} \mathrm{C}$ $30 \mathrm{~min}, 72 \%$. (c) NBS, $\mathrm{CHCl}_{3}, \mathrm{AcOH}$, room temp., $15 \mathrm{~min}$; then CPDIPS acetylene, $\mathrm{Pd}\left(\mathrm{PPh}_{3}\right)_{4}, \mathrm{Cul}$, toluene, diisopropylamine, $100{ }^{\circ} \mathrm{C}, 20 \mathrm{~h}, 63 \%$ (two steps). (d) TBAF, THF, room temp., $20 \mathrm{~h}, 97 \%$. (e) $\mathrm{CuCl}, \mathrm{Cu}(\mathrm{OAc})_{2}$, pyridine, room temp., $48 \mathrm{~h}, 33 \%$. (f) $\mathrm{Na}_{2} \mathrm{~S} \cdot 9 \mathrm{H}_{2} \mathrm{O}, \mathrm{DMF}, 2$-methoxyethanol, $120^{\circ} \mathrm{C}, 1.5 \mathrm{~h}$, quant. 


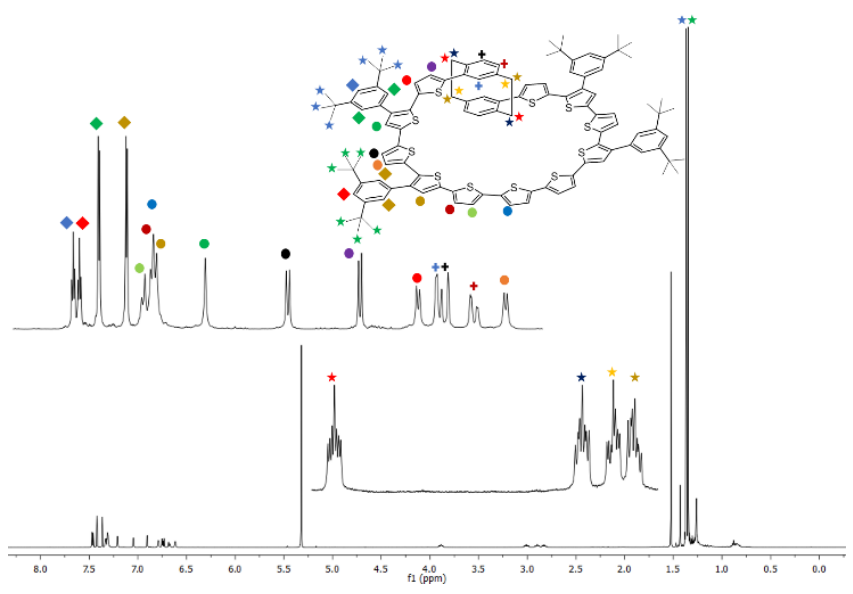

Figure 2. ${ }^{1} \mathrm{H}$ NMR spectrum of macrocycle 1 in $\mathrm{CD}_{2} \mathrm{Cl}_{2}$ at room temperature. Inlet: aromatic (top) and benzylic (bottom) protons of $\mathbf{1}$

The identity of macrocycle 1 was fully corroborated by ${ }^{1} \mathrm{H}$ and ${ }^{13} \mathrm{C} \mathrm{NMR}$ as well as by $2 \mathrm{D}$ NMR spectroscopy, which enabled us to fully assign the observed resonances to the corresponding proton and carbon atoms. All recorded spectra of $\mathbf{1}$ are available in the supporting information (SI); its ${ }^{1} \mathrm{H}$ NMR spectrum recorded at $600 \mathrm{MHz}$ is displayed in figure 2 to demonstrate both, purity and identity of the isolated target structure. The elemental formula of $\mathbf{1}$ was confirmed by high-resolution matrix-assisted laser desorption/ionization time-offlight mass spectrometry (HR MALDI-TOF MS, displayed in figure S57 in the $\mathrm{SI}$ ). The signal observed for $\mathbf{1}$ showed an isotopic pattern matching the one expected for its elemental composition ([M] ${ }^{+}$ $\mathrm{C}_{116} \mathrm{H}_{116} \mathrm{~S}_{11}$ ).

The macrocyclization of $\mathbf{2 2}$ to $\mathbf{2 3}$ yields the product as a racemic mixture. Both enantiomers for macrocycles $\mathbf{2 3}$ and $\mathbf{1}$ can readily interconvert through a concerted rotation around the $\mathrm{C}-\mathrm{C}$ bonds between the benzene rings of the $\mathrm{PC}$ and the thiophene building blocks on each adjacent side (see figure 3 ). We investigated the racemization dynamics for macrocycle $\mathbf{1}$. The rotation proceeds rapidly at room temperature, separation of the enantiomers by means of HPLC on a chiral stationary phase was not possible. It is worth to note that the racemization does not proceed through an achiral transition state, unlike in the cases of helicenes, twistacenes or banister- like molecules because the pseudo-para substituted PC does not allow for a symmetry element along the reaction coordinate that renders the transition state to be achiral..$^{[53,54]}$

To further investigate the dynamics of the racemization, $\mathbf{1}$ was subjected to VT-NMR experiments in $\mathrm{CD}_{2} \mathrm{Cl}_{2}$. The most instructive picture of the dynamics is obtained when the resonances of the four $\mathrm{CH}_{2}$-groups of the $\mathrm{PC}$ unit are analyzed at different temperatures. For
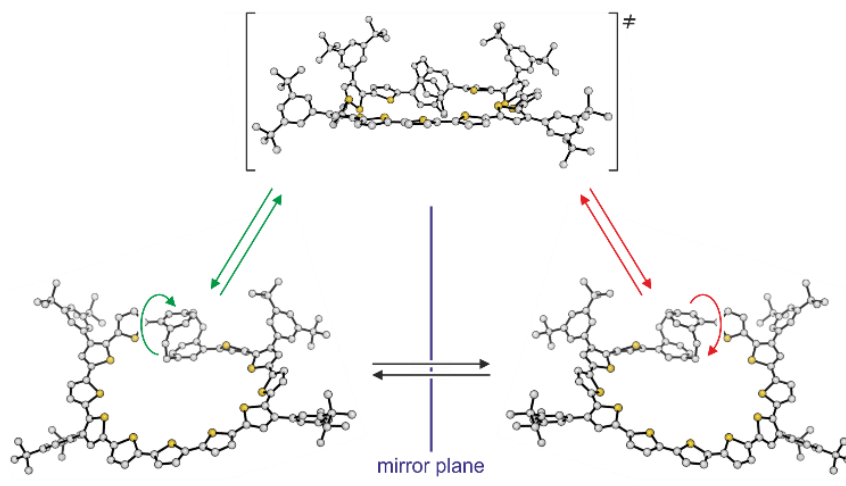

Figure 3. Graphical representation of both enantiomers of macrocycle 1 together with a transition state of the enantiomerization process. Rotation around the bonds between the oligothiophene-belt and the [2.2]paracyclophane interconverts one enantiomer into the other. the static, chiral structure of $\mathbf{1}$, these eight protons are all magnetically inequivalent, and, hence, eight resonances are expected. At room temperature, however, only four distinct complex multiplets are observed in the range between 2.5 and $4.0 \mathrm{ppm}$. This clearly demonstrates racemization kinetics that is fast on the ${ }^{1} \mathrm{H}$-NMR time scale. Depending on the concentration of the sample, the resonances appear as sharp resolved signals (c.f. figure 2) or, at higher concentration, stacking of the extended aromatic ring systems leads to broadening which is not related to a dynamic process originating in the racemization. When the temperature was lowered to $218 \mathrm{~K}$, severe line broadening occurs and after coalescence at approximately $213 \mathrm{~K}$ a splitting into eight, partially overlapping signals was observed indicating slow interconversion of the enantiomers by the rubber glove mechanism (see figure 4). The activation barrier for the racemization was determined from the shift difference of $417 \mathrm{~Hz}$ for $\mathrm{H}-41 / \mathrm{H}-41 \mathrm{a}$ and the coalescence temperature $(213 \mathrm{~K})$ to be $38 \mathrm{~kJ} \mathrm{~mol}^{-1}$. The barrier for racemization is considerably lower than the barrier for similar ferrocene-based macrocycles with smaller ring sizes. ${ }^{[5]}$ Further cooling of the sample to $183 \mathrm{~K}$ revealed a second dynamic process

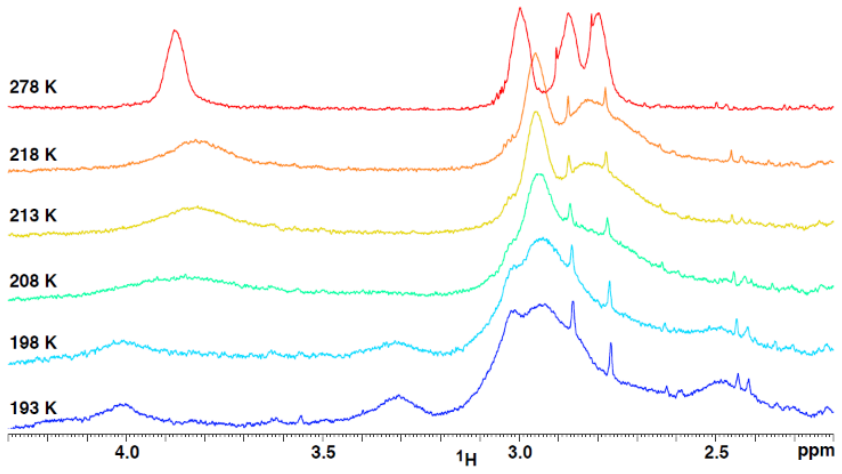

Figure 4. VT-NMR spectra of the resonances, corresponding to the benzylic protons of $\mathbf{1}$.

that is most likely related to rotational restrictions in the di-tertbutylphenyl units.

To investigate the change in through-space vs. through-bond conjugation by the introduced macrocycle, the optoelectronical properties of macrocycles $\mathbf{2 3}$ and $\mathbf{1}$ were investigated by UV/Vis absorption and emission spectroscopy and compared to linear building block $\mathbf{2 2}$ (figure 5). The terminal alkyne substituted oligothiophene with a central PC subunit $\mathbf{2 2}$ has its absorption maximum at $438 \mathrm{~nm}$. After macrocyclization, the absorption maxima of $\mathbf{2 3}$ and $\mathbf{1}$ are hypsochromically shifted with respect to $\mathbf{2 2}$. The absorption maximum of $\mathbf{2 3}$ is found at $413 \mathrm{~nm}$ and the absorption maximum of $\mathbf{1}$ is at $420 \mathrm{~nm}$. Both absorption spectra of the macrocyclic compounds display additional shoulders, one is found around $450 \mathrm{~nm}$, which is more pronounced in the case of $\mathbf{2 3}$, the other appears at wavelengths higher than $500 \mathrm{~nm}$. The comparison of the absorption spectrum of $\mathbf{2 2}$ with reported electronic data from linear oligothiophenes points at through-space conjugation in the central PC subunit. Penta- and heptathiophenic oligomers have absorption maxima at 386 and 409 $\mathrm{nm}$, respectively. ${ }^{[56]}$ The absorption maximum of 22, consisting of two pentathiophenes interlinked by PC, is at $438 \mathrm{~nm}$. The bathochromic shift compared to the reported oligothiophenes confirms the throughspace conjugation in the central PC subunit, as already reported for similar compounds. ${ }^{[34-36]}$ Macrocyclic thiophenes of a given size have absorption maxima that correspond in energy to the absorption maxima of linear oligothiophenes of approximately half the number of thiophene subunits. ${ }^{[56]}$ The hypsochromic shift of the absorption maxima of the macrocycles $\mathbf{2 3}$ and $\mathbf{1}$ compared to linear $\mathbf{2 2}$ was thus not surprising. Also, the rather small values of $25 \mathrm{~nm}$ and $18 \mathrm{~nm}$ of the recorded shifts for $\mathbf{2 3}$ and $\mathbf{1}$ respectively can be rationalized by the 


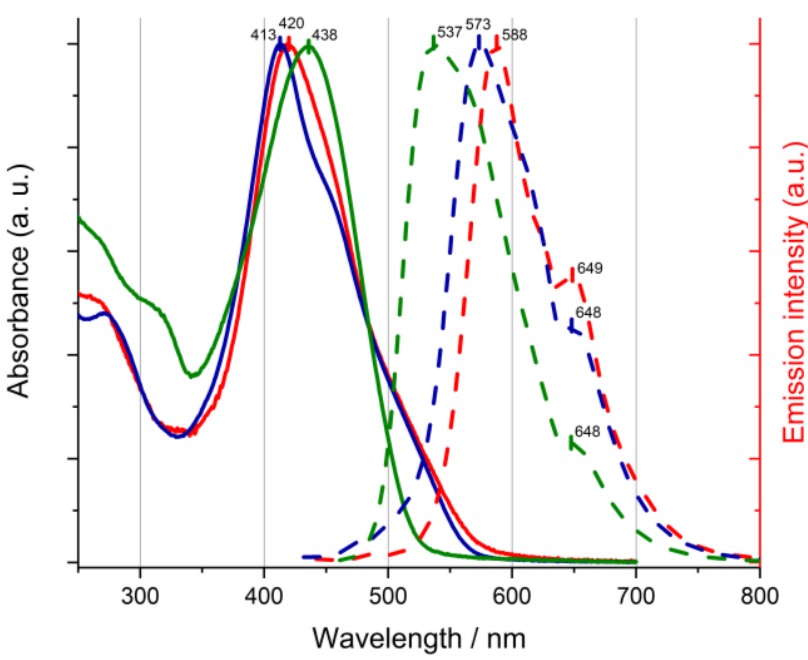

Figure 5. Absorption spectra of $\mathbf{2 2}$ (green line), $\mathbf{2 3}$ (blue line) and $\mathbf{1}$ (red line) and emission spectra (dotted lines of corresponding color). All spectra were recorded in dichloromethane at room temperature. The emission spectra were exited at $438 \mathrm{~nm}$ (22), $413 \mathrm{~nm}$ (23), and $420 \mathrm{~nm}$ (1).

through-space conjugation in the central PC unit of the linear precursor 22. Compared with an oligomer of comparable length consisting exclusively of 2,5-interlinked thiophenes, the through-space conjugation is less effective than the delocalization in a thiophene, resulting in a larger separation of the frontier orbitals. The bathochromic shift of $7 \mathrm{~nm}$ of the absorption maximum of $\mathbf{1}$ compared to the signal of macrocycle $\mathbf{2 3}$ points at the increased delocalization through the $s p^{2}$ carbon atoms of the 2,5-diyl-thiophene linker in $\mathbf{1}$ (through-bond conjugation) compared with the $s p$ centers of the diacetylene connection in $\mathbf{2 3}$.

The emission spectra of all three samples $\mathbf{2 2}, \mathbf{2 3}$, and $\mathbf{1}$ have an intense maximum with a more or less pronounced shoulder at about 648-649 $\mathrm{nm}$ in common. While the maximum of the emission of $\mathbf{2 2}$ is at 537 with a Stokes' shift of $99 \mathrm{~nm}$, the one of $\mathbf{2 3}$ is at $573 \mathrm{~nm}$ with a Stokes' shift of $160 \mathrm{~nm}$ and the emission maximum of $\mathbf{1}$ is at $588 \mathrm{~nm}$ with a Stokes' shift of $168 \mathrm{~nm}$. Again, a bathochromic shift with increasing conjugation in the macromolecules' subunits is observed in the order of the emission signals.

Initial attempts to measure the HOMO-LUMO gap electrochemically failed due to irreversible behavior of $\mathbf{1}$ in the cyclic voltammetry experiment. As approximations of the HOMO-LUMO gaps, the electronic transitions between the vibrational ground states of the absorption and emission spectra were compared. For the linear precursor 22, the absorption and emission bands intersect at $500 \mathrm{~nm}$, corresponding to a transition energy of $2.48 \mathrm{eV}$. The intersection is bathochromically shifted to $528 \mathrm{~nm}(2.35 \mathrm{eV})$ for the cyclized 23 and shifts further to $542 \mathrm{~nm}(2.29 \mathrm{eV})$ upon replacing the diacetylene linkage with a thiophene subunit in $\mathbf{1}$. The decrease of transition energies further corroborates the trend of increasing conjugation in the subunits of the investigated series.

\section{Conclusions}

We present an efficient synthesis of chiral macrocycle $\mathbf{1}$ and its full characterization by ${ }^{1} \mathrm{H},{ }^{13} \mathrm{C}$ and $2 \mathrm{D}$ NMR spectroscopy as well as high resolution mass spectrometry. Suitable precursors to incorporate PC as a key building block to break the conjugation of the macrocycle were designed and synthesized. The assembly of the achiral linear precursors is based on Pd- catalyzed coupling chemistry combined with halogenation sequences of the corresponding thiophenes. A linear synthetic strategy allowed to determine the required length of the precursor for a successful macrocyclization. The ring closing as key step of the synthesis provided the target molecule in reasonable yields, considering both its size and structural flexibility. The macrocyclization yielded a racemic mixture that could not be resolved due to the low racemization barrier at room temperature. The racemization barrier was investigated with VT-NMR experiments and was found to be $38 \mathrm{~kJ}$ $\mathrm{mol}^{-1}$, indicating unhindered rotation of the central PC unit versus the oligothiophenic chain at room temperature. Investigation of the optical properties of the obtained macrocycles and comparison with the open-ring precursor allowed to determine the change of electronic features upon macrocyclization. All spectra of the macrocycles were considerably red-shifted compared to the open-ring precursor. We obtained rare insights into the through-space versus through-bond conjugation through the comparison of the considerable lowered transition energies between vibrational ground states.

In summary, two unique conjugated macrocycles have been prepared and investigated, elucidating the influence of a prochiral building block with broken conjugation on structural and electronical properties.

We are currently advancing the concept of helical chiral oligothiophene macrocycles comprising a PC subunit by designing model compounds of increased stability due to sterically hindered enantiomerization processes.

\section{Experimental Section}

General

Instruments, materials and methods are described in detail in the Supporting Information.

Previously Described Compounds

4,16-Dibromo[2.2]paracyclophane, trimethyl(5-(4,4,5,5-tetramethyl1,3,2-dioxaborolan-2-yl)thien-2-yl)silane, 2-(3,5-di-tert-butylphenyl)4,4,5,5-tetramethyl-1,3,2-dioxaborolane and CPDIPS-acetylene were prepared according to reported procedures. ${ }^{[47,48,51,57]}$

\section{Experimental}

3-(3,5-Di-tert-butylphenyl)thiophene (11): 2-(3,5-Di-tert-butylphenyl)-4,4,5,5-tetramethyl-1,3,2-dioxaborolane ${ }^{[48]}(12.9 \mathrm{~g}, 40.7 \mathrm{mmol}$, 1.05 eq.), 3-bromothiophene ( $3.64 \mathrm{~mL}, 38.8 \mathrm{mmol}, 1.00$ eq.), $\mathrm{Na}_{2} \mathrm{CO}_{3}$ $\left(20.5 \mathrm{~g}, 194 \mathrm{mmol}, 5.00 \mathrm{eq}\right.$.) and $\mathrm{Pd}\left(\mathrm{PPh}_{3}\right)_{4}(1.12 \mathrm{~g}, 970 \mu \mathrm{mol}$, $2.5 \mathrm{~mol} \%)$ were suspended in a mixture of DMF $(54 \mathrm{~mL})$ and $\mathrm{H}_{2} \mathrm{O}$ $(6 \mathrm{~mL})$. The reaction mixture was degassed by bubbling a stream of argon through the solution and was heated to $120^{\circ} \mathrm{C}$ for two hours. The reaction was allowed to reach room temperature, toluene was added, and the organic phase was washed with $2 \mathrm{M} \mathrm{HCl}$ and dried over $\mathrm{MgSO}_{4}$. The solvent was removed under reduced pressure and the crude was purified by column chromatography (pentane), yielding $\mathbf{1 1}$ as a colorless oil $(9.35 \mathrm{~g}, 34.3 \mathrm{mmol}, 88 \%)$. ${ }^{1} \mathrm{H}$ NMR $\left(250 \mathrm{MHz}, \mathrm{CD}_{2} \mathrm{Cl}_{2}\right)$ $\delta=7.47-7.38(\mathrm{~m}, 6 \mathrm{H}), 1.37(\mathrm{~s}, 18 \mathrm{H}) \mathrm{ppm} .{ }^{13} \mathrm{C}$ NMR $\left(101 \mathrm{MHz}, \mathrm{CD}_{2} \mathrm{Cl}_{2}\right)$ $\delta=151.88,135.76,127.89,127.29,126.52,122.00,121.49,120.56$, $35.39,31.79$ ppm. MS (El, $70 \mathrm{eV}): m / z(\%)=272.20(48.90), 257.20$ (100), 57.10 (73.16). HRMS (El): $\mathrm{m} / z$ calcd. for: $\mathrm{C}_{18} \mathrm{H}_{24} \mathrm{~S}^{+}\left[\mathrm{M}^{+}\right]$: 272.1594 ; found 272.1598.

2-Bromo-3-(3,5-di-tert-butylphenyl)thiophene (12): 3-(3,5)-Ditert-butylphenyl)thiophene (11) $(9.33 \mathrm{~g}, 34.3 \mathrm{mmol}, 1.00 \mathrm{eq}$.) was 
dissolved in $\mathrm{CHCl}_{3}(100 \mathrm{~mL})$ and $\mathrm{AcOH}(100 \mathrm{~mL})$. To this was added under exclusion of light, NBS $(6.11 \mathrm{~g}, 34.3 \mathrm{mmol}, 1.00 \mathrm{eq})$ and the reaction was heated to $40{ }^{\circ} \mathrm{C}$ for one hour. The reaction was allowed to reach room temperature, $\mathrm{CH}_{2} \mathrm{Cl}_{2}$ was added and the reaction was neutralized with sat. aq. $\mathrm{NaHCO}_{3}$. It was dried over $\mathrm{MgSO}_{4}$ and the solvent was removed in vacuo. The crude was purified by column chromatography (cyclohexane), yielding $\mathbf{1 2}$ as a colorless oil $(9.27 \mathrm{~g}$, $26.4 \mathrm{mmol}, 77 \%)$. ${ }^{1} \mathrm{H} \mathrm{NMR}\left(400 \mathrm{MHz}, \mathrm{CD}_{2} \mathrm{Cl}_{2}\right) \delta=7.45\left(\mathrm{t},{ }^{4} \mathrm{~J}=1.8 \mathrm{~Hz}\right.$ $1 \mathrm{H}), 7.41\left(\mathrm{~d},{ }^{4} \mathrm{~J}=1.8 \mathrm{~Hz}, 2 \mathrm{H}\right), 7.35\left(\mathrm{~d},{ }^{3} J=5.6 \mathrm{~Hz}, 1 \mathrm{H}\right), 7.08\left(\mathrm{~d},{ }^{3} J=5.6\right.$ $\mathrm{Hz}, 1 \mathrm{H}), 1.37(\mathrm{~s}, 18 \mathrm{H}) \mathrm{ppm} .{ }^{13} \mathrm{C} \mathrm{NMR}\left(101 \mathrm{MHz}, \mathrm{CD}_{2} \mathrm{Cl}_{2}\right) \delta=151.48$, $142.81,134.60,129.88,126.45,123.63,122.27,108.62,35.45,31.77$ ppm. MS (El, $70 \mathrm{eV}): m / z(\%)=352.20$ (28.89), 350.15 (28.84), 337.15 (75.23), 335.15 (72.64), 57.10 (100). $\mathrm{C}_{18} \mathrm{H}_{23} \mathrm{BrS}$ (351.346): calcd. C 61.53 H 6.60; found C 61.65 H 6.87 .

\section{2-(3-(3,5-Di-tert-butylphenyl)thien-2-yl)-4,4,5,5-tetramethyl-} 1,3,2-dioxaborolane (7): 2-Bromo-3-(3,5-di-tert-butylphenyl)thiophene (12) $(3.45 \mathrm{~g}, 9.83 \mathrm{mmol}, 1.0$ eq.) was dissolved in THF $(60 \mathrm{~mL})$ and was degassed with argon. The reaction mixture was cooled to $-78^{\circ} \mathrm{C}$ and $n$-BuLi $(1.6 \mathrm{M}$ in hexane, $6.14 \mathrm{~mL}, 9.83 \mathrm{mmol}$, 1.0 eq.) was added dropwise. The reaction was stirred for two hours and 2-isopropoxy-4,4,5,5-tetramethyl-1,3,2-dioxaborolane $(2.21 \mathrm{~mL}$, $10.8 \mathrm{mmol}, 1.10 \mathrm{eq}$.) was added dropwise. The reaction was allowed to reach room temperature and $2 \mathrm{M} \mathrm{HCl}$ was added. The crude was taken up in toluene and filtered through a plug of celite. The solvent was removed, and $\mathbf{7}$ was obtained as brown oil, which solidified upon standing $(3.51 \mathrm{~g}, 8.86 \mathrm{mmol}, 90 \%)$. M.p.: $69-71^{\circ} \mathrm{C} .{ }^{1} \mathrm{H} \mathrm{NMR}(400 \mathrm{MHz}$ $\left.\mathrm{CDCl}_{3}\right) \delta=7.60\left(\mathrm{~d},{ }^{3} J=4.8 \mathrm{~Hz}, 1 \mathrm{H}\right), 7.47\left(\mathrm{~d},{ }^{4} \mathrm{~J}=1.8 \mathrm{~Hz}, 2 \mathrm{H}\right), 7.40\left(\mathrm{t},{ }^{4} \mathrm{~J}\right.$ $=1.8 \mathrm{~Hz}, 1 \mathrm{H}), 7.31\left(\mathrm{~d},{ }^{3} J=4.8 \mathrm{~Hz}, 1 \mathrm{H}\right), 1.39(\mathrm{~s}, 18 \mathrm{H}), 1.31(\mathrm{~s}, 12 \mathrm{H}) \mathrm{ppm}$. ${ }^{13} \mathrm{C}$ NMR $\left(101 \mathrm{MHz}, \mathrm{CDCl}_{3}\right) \delta=153.02,149.96,136.33,131.64,131.36$, $123.82,121.37,83.99,35.05,31.69,24.94 \mathrm{ppm}$. The carbon, to which the boron is bound is not observed. HRMS (EI): $\mathrm{m} / \mathrm{z}$ calcd. for: $\mathrm{C}_{24} \mathrm{H}_{35} \mathrm{BO}_{2} \mathrm{~S}^{+}\left[M^{+}\right]$: 398.2450; found 398.2452.

4,16-Dithienyl[2.2]paracyclophane (6): 4,16-Dibromo[2.2]paracyclophane $\left(4.58 \mathrm{~g}, 12.5 \mathrm{mmol}, 1.0 \mathrm{eq}\right.$.) and $\mathrm{Pd}(\mathrm{dppf}) \mathrm{Cl}_{2} \quad(229 \mathrm{mg}$ $313 \mu \mathrm{mol}, 2.5 \mathrm{~mol} \%)$ were suspended in THF $(100 \mathrm{~mL})$ and degassed with argon. To this was added thienyl magnesium bromide $(1.0 \mathrm{M}$ in $\mathrm{THF}, 50.0 \mathrm{~mL} 50.0 \mathrm{mmol}, 4.0$ eq.) and the reaction was heated to $60^{\circ} \mathrm{C}$ for two hours. The reaction was allowed to reach room temperature and sat. aq. $\mathrm{NH}_{4} \mathrm{Cl}$ was added. The organic phase was diluted with $\mathrm{CH}_{2} \mathrm{Cl}_{2}$ and was washed with $2 \mathrm{M} \mathrm{HCl}$. The solvent was removed under reduced pressure and the crude was washed with cyclohexane and cold $\mathrm{CH}_{2} \mathrm{Cl}_{2}$ and dried. 6 was obtained as a white solid $(4.06 \mathrm{~g}$, $10.9 \mathrm{mmol}, 87 \%)$. The analytical data agreed with the values reported in literature. ${ }^{[36]}{ }^{1} \mathrm{H}$ NMR $\left(400 \mathrm{MHz}, \mathrm{CDCl}_{3}\right) \delta=7.39\left(\mathrm{dd}^{3}{ }^{3} \mathrm{~J}=4.9 \mathrm{~Hz}_{1}{ }^{4} \mathrm{~J}=\right.$ $1.4 \mathrm{~Hz}, 2 \mathrm{H}), 7.16-7.11(\mathrm{~m}, 4 \mathrm{H}), 6.74\left(\mathrm{dd},{ }^{3} J=7.8 \mathrm{~Hz},{ }^{4} J=2.0 \mathrm{~Hz}, 2 \mathrm{H}\right)$, $6.66\left(\mathrm{~d},{ }^{4} \mathrm{~J}=2.0 \mathrm{~Hz}, 2 \mathrm{H}\right), 6.59\left(\mathrm{~d},{ }^{3} \mathrm{~J}=7.8 \mathrm{~Hz}, 2 \mathrm{H}\right), 3.77-3.69(\mathrm{~m}, 2 \mathrm{H})$, $3.01-2.85(\mathrm{~m}, 4 \mathrm{H}) \mathrm{ppm} .{ }^{13} \mathrm{C}$ NMR $\left(101 \mathrm{MHz}, \mathrm{CD}_{2} \mathrm{Cl}_{2}\right) \delta=144.35,140.26$ $137.35,135.08,135.05,133.66,129.77,127.74,126.13,125.38,34.54$, $34.17 \mathrm{ppm}$. MS (El, $70 \mathrm{eV}): \mathrm{m} / z(\%)=373.20$ (13.43), 372.25 (48.76), 187.10 (100), 185.10 (68.51), 171.10 (48.12), 141.15 (24.68), 115.15 (14.17).

4,16-Di-(5-bromothienyl)[2.2]paracyclophane (15): 4,16-Dithien$\mathrm{yl}[2.2]$ paracyclophane $(6)(4.06 \mathrm{~g}, 10.9 \mathrm{mmol}, 1.00 \mathrm{eq}$.) was suspended in $\mathrm{CHCl}_{3}(75 \mathrm{~mL})$ and DMF $(75 \mathrm{~mL})$ and under exclusion of light NBS ( $3.98 \mathrm{~g} 22.3 \mathrm{mmol} 2.05 \mathrm{eq}$.) was added. The reaction was allowed to proceed for 20 hours and $2 \mathrm{M} \mathrm{HCl}$ was added. The organic layer was washed with $2 \mathrm{M} \mathrm{HCl}$ and dried over $\mathrm{MgSO}_{4}$. The solvent was removed under reduced pressure, the crude was taken up in toluene and filtered through a plug of celite. 15 was obtained as a white solid after solvent removal $(5.23 \mathrm{~g}, 9.86 \mathrm{mmol}, 91 \%)$. M.p.: $240-242^{\circ} \mathrm{C} .{ }^{1} \mathrm{H}$ NMR $(400$ $\left.\mathrm{MHz}_{2} \mathrm{CDCl}_{3}\right) \delta=7.09\left(\mathrm{~d}^{3}{ }^{3} \mathrm{~J}=3.8 \mathrm{~Hz}, 2 \mathrm{H}\right), 6.86\left(\mathrm{~d},{ }^{3} \mathrm{~J}=3.8 \mathrm{~Hz}, 2 \mathrm{H}\right), 6.74$ $\left(\mathrm{dd}^{3}{ }^{3} \mathrm{~J}=7.8 \mathrm{~Hz},{ }^{4} J=2.0 \mathrm{~Hz}, 2 \mathrm{H}\right), 6.57-6.53(\mathrm{~m}, 4 \mathrm{H}), 3.72-3.64(\mathrm{~m}, 2 \mathrm{H})$, $3.00-2.86(\mathrm{~m}, 6 \mathrm{H}) \mathrm{ppm} .{ }^{13} \mathrm{C} \mathrm{NMR}\left(101 \mathrm{MHz}, \mathrm{CDCl}_{3}\right) \delta=145.83,140.36$, 137.30, 135.13, 134.40, 133.39, 130.64, 130.06, 126.39, 111.80, 34.47, 34.03 ppm. HRMS (El): $\mathrm{m} / \mathrm{z}$ calcd. for: $\mathrm{C}_{24} \mathrm{H}_{18} \mathrm{Br}_{2} \mathrm{~S}_{2}{ }^{+}\left[M^{+}\right.$]: 527.9212; found 527.9216 .
4,16-Di-(3'-(3,5-di-tert-butylphenyl))-[2,2'-bithien]-5-yl-[2.2]paracyclophane 16: 4,16-Di-(5-bromothienyl)[2.2]paracyclophane 15 (340 mg, $640 \mu \mathrm{mol}, 1.00$ eq.), boronic ester 7 (770 mg, $1.93 \mathrm{mmol}$, 3.00 eq.) and $\mathrm{K}_{2} \mathrm{CO}_{3}(532 \mathrm{mg}, 3.85 \mathrm{mmol}, 6.00$ eq.) were suspended in toluene $(10 \mathrm{~mL})$ and $\mathrm{MeOH}(10 \mathrm{~mL})$. The reaction mixture was degassed with argon and Pd-PEPPSI-IPr ${ }^{\mathrm{TM}}(22.2 \mathrm{mg}, 32.1 \mu \mathrm{mol}$, $5 \mathrm{~mol} \%$ ) was added. The reaction mixture was placed in a preheated oil bath and the reaction was stirred at $70{ }^{\circ} \mathrm{C}$ for 15 minutes. The reaction was allowed to reach room temperature and the organic layer was washed with $2 \mathrm{M} \mathrm{HCl}$. It was dried over $\mathrm{MgSO}_{4}$ and the solvent was removed under reduced pressure. The crude was purified by column chromatography (cyclohexane/ $\mathrm{CH}_{2} \mathrm{Cl}_{2}$ 4:1) and $\mathbf{1 6}$ was obtained as an off-white solid ( $557 \mathrm{mg}, 610 \mu \mathrm{mol}, 95 \%)$. M.p.: $>250^{\circ} \mathrm{C}$. ${ }^{1} \mathrm{H}$ NMR $(400$ $\left.\mathrm{MHz}, \mathrm{CD}_{2} \mathrm{Cl}_{2}\right) \delta=7.44\left(\mathrm{t},{ }^{4} \mathrm{~J}=1.9 \mathrm{~Hz}, 2 \mathrm{H}\right), 7.34\left(\mathrm{~d},{ }^{3} J=5.2 \mathrm{~Hz}, 2 \mathrm{H}\right), 7.32$ $\left(\mathrm{d},{ }^{4} \mathrm{~J}=1.8 \mathrm{~Hz}, 4 \mathrm{H}\right), 7.16\left(\mathrm{~d},{ }^{3} \mathrm{~J}=5.2 \mathrm{~Hz}, 2 \mathrm{H}\right), 7.00\left(\mathrm{~d},{ }^{3} \mathrm{~J}=3.7 \mathrm{~Hz}, 2 \mathrm{H}\right)$, $6.93\left(d^{3}{ }^{3}=3.7 \mathrm{~Hz}, 2 \mathrm{H}\right), 6.61\left(\mathrm{dd},{ }^{3} J=7.8 \mathrm{~Hz},{ }^{4}=1.9 \mathrm{~Hz}, 2 \mathrm{H}\right), 6.51(\mathrm{~d}$, $\left.{ }^{4} J=1.9 \mathrm{~Hz}, 2 \mathrm{H}\right), 6.43\left(\mathrm{~d},{ }^{3} \mathrm{~J}=7.8 \mathrm{~Hz}, 2 \mathrm{H}\right), 3.69-3.60(\mathrm{~m}, 2 \mathrm{H}), 2.92-2.78$ $(\mathrm{m}, 6 \mathrm{H}), 1.33(\mathrm{~s}, 36 \mathrm{H}) \mathrm{ppm} .{ }^{13} \mathrm{C}$ NMR $\left(101 \mathrm{MHz}, \mathrm{CD}_{2} \mathrm{Cl}_{2}\right) \delta=151.47$, $144.82,140.77,140.69,137.69,136.65,135.89,135.48,135.22,133.65$, $132.11,131.21,130.17,127.64,126.66,124.40,124.29,121.92,35.40$, $34.77,34.48,31.80 \mathrm{ppm}$. HRMS (MALDI TOF, DCTB): $\mathrm{m} / \mathrm{z}$ calcd for $\mathrm{C}_{60} \mathrm{H}_{64} \mathrm{~S}_{4}{ }^{+}\left[M^{+}\right]:$: 12.3885 , found: 912.3882 .

4,16-Di-(5'-bromo-3'-(3,5-di-tert-butylphenyl))-[2,2'-bithien]-5yl-[2.2] paracyclophane 17: Tetrathiophene $16(400 \mathrm{mg}, 440 \mu \mathrm{mol}$, $1.00 \mathrm{eq})$ was dissolved in DMF $(25 \mathrm{~mL})$ and to this was added in the dark NBS $(160 \mathrm{mg}, 900 \mu \mathrm{mol}, 2.05 \mathrm{eq}$.). The reaction was stirred at room temperature for 20 hours and toluene was added to the reaction mixture. The organic layer was washed with $2 \mathrm{M} \mathrm{HCl}$ and was dried over $\mathrm{MgSO}_{4}$. The solvent was removed under reduced pressure and the crude product was purified by column chromatography $\left(\mathrm{CH}_{2} \mathrm{Cl}_{2} /\right.$ cyclohexane 1:9). 17 was isolated as a yellow solid (432 mg, $400 \mu \mathrm{mol}, 92 \%)$. M.p.: $250-252{ }^{\circ} \mathrm{C} .{ }^{1} \mathrm{H}$ NMR $\left(400 \mathrm{MHz}, \mathrm{CD}_{2} \mathrm{Cl}_{2}\right)$ $\delta=7.44\left(\mathrm{t}^{4}{ }^{\mathrm{J}} \mathrm{J}=1.9 \mathrm{~Hz}, 2 \mathrm{H}\right), 7.27\left(\mathrm{~d},{ }^{4} \mathrm{~J}=1.9 \mathrm{~Hz}, 4 \mathrm{H}\right), 7.14(\mathrm{~s}, 2 \mathrm{H}), 6.98$ $\left(d^{3}{ }^{3} J=3.8 \mathrm{~Hz}, 2 \mathrm{H}\right), 6.92\left(\mathrm{~d},{ }^{3} \mathrm{~J}=3.8 \mathrm{~Hz}, 2 \mathrm{H}\right), 6.58\left(\mathrm{dd}^{3}{ }^{3} \mathrm{~J}=7.8 \mathrm{~Hz},{ }^{4} \mathrm{~J}=\right.$ $1.9 \mathrm{~Hz}, 2 \mathrm{H}), 6.48\left(\mathrm{~d},{ }^{4} \mathrm{~J}=1.9 \mathrm{~Hz}, 2 \mathrm{H}\right), 6.40\left(\mathrm{~d},{ }^{3} \mathrm{~J}=7.8 \mathrm{~Hz}, 2 \mathrm{H}\right), 3.65-3.57$ $(\mathrm{m}, 2 \mathrm{H}), 2.91-2.78(\mathrm{~m}, 6 \mathrm{H}), 1.32(\mathrm{~s}, 36 \mathrm{H}) \mathrm{ppm} .{ }^{13} \mathrm{C}$ NMR $(101 \mathrm{MHz}$, $\left.\mathrm{CD}_{2} \mathrm{Cl}_{2}\right) \delta=151.64,145.36,141.13,140.70,137.72,135.48,135.05$, $134.82,133.86,133.65,133.56,131.92,130.26,127.99,126.67,124.17$, $122.36,110.97,35.41,34.75,34.43,31.77 \mathrm{ppm}$. HRMS (MALDI TOF, DCTB): $m / z$ calcd for $\mathrm{C}_{60} \mathrm{H}_{62} \mathrm{Br}_{2} \mathrm{~S}_{4}{ }^{+}\left[M^{+}\right]:$1068.2096, found: 1068.2095.

\section{4,16-Di-(3'-(3,5-di-tert-butylphenyl))-5"'-trimethylsilyl-}

[2,2':5',2'"-terthien]-5-yl-[2.2] paracyclophane 18: Dibromide 17 $(800 \mathrm{mg}, 750$ umol, 1.00 eq.), boronic ester $8(845 \mathrm{mg}, 2.99 \mathrm{mmol}$, 4.00 eq.) and $\mathrm{K}_{2} \mathrm{CO}_{3}(619 \mathrm{mg}, 4.48 \mathrm{mmol}, 6.00$ eq.) were suspended in toluene $(25 \mathrm{~mL})$ and $\mathrm{MeOH}(25 \mathrm{~mL})$. The reaction mixture was degassed with argon and Pd-PEPPSI-IPrTM $(25.9 \mathrm{mg}, 37.4 \mu \mathrm{mol}$, $5 \mathrm{~mol} \%$ ) was added. The reaction mixture was placed in a preheated oil bath and the reaction was stirred at $70{ }^{\circ} \mathrm{C}$ for 20 minutes. The reaction was allowed to reach room temperature and the organic layer was washed with $2 \mathrm{M} \mathrm{HCl}$. It was dried over $\mathrm{MgSO}_{4}$ and the solvent was removed under reduced pressure. The crude was purified by column chromatography (cyclohexane/ $\mathrm{CH}_{2} \mathrm{Cl}_{2}$ 9:1) and $\mathbf{1 8}$ was obtained as a yellow wax (744 mg, $610 \mu \mathrm{mol}, 82 \%) .{ }^{1} \mathrm{H}$ NMR $\left(400 \mathrm{MHz}_{1} \mathrm{CD}_{2} \mathrm{Cl}_{2}\right)$ $\delta=7.27\left(\mathrm{t}^{4}{ }^{4} \mathrm{~J}=1.9 \mathrm{~Hz}, 2 \mathrm{H}\right), 7.14\left(\mathrm{~d},{ }^{4} \mathrm{~J}=1.9 \mathrm{~Hz}, 4 \mathrm{H}\right), 7.12\left(\mathrm{~d},{ }^{3} \mathrm{~J}=3.5 \mathrm{~Hz}\right.$, $2 \mathrm{H}), 7.03(\mathrm{~s}, 2 \mathrm{H}), 7.00\left(\mathrm{~d},{ }^{3} \mathrm{~J}=3.5 \mathrm{~Hz}, 2 \mathrm{H}\right), 6.82\left(\mathrm{~d},{ }^{3} \mathrm{~J}=3.8 \mathrm{~Hz}, 2 \mathrm{H}\right), 6.72$ $\left(\mathrm{d},{ }^{3} \mathrm{~J}=3.8 \mathrm{~Hz}, 2 \mathrm{H}\right), 6.39\left(\mathrm{dd},{ }^{3} \mathrm{~J}=7.8 \mathrm{~Hz},{ }^{4} J=1.9 \mathrm{~Hz}, 2 \mathrm{H}\right), 6.29\left(\mathrm{~d},{ }^{4} \mathrm{~J}=\right.$ $1.9 \mathrm{~Hz}, 2 \mathrm{H}), 6.21\left(\mathrm{~d},{ }^{3} \mathrm{~J}=7.8 \mathrm{~Hz}, 2 \mathrm{H}\right), 3.48-3.38(\mathrm{~m}, 12 \mathrm{H}), 2.71-2.60$ $(\mathrm{m}, 6 \mathrm{H}), 1.14(\mathrm{~s}, 36 \mathrm{H}), 0.15(\mathrm{~s}, 18 \mathrm{H}) \mathrm{ppm} .{ }^{13} \mathrm{C}$ NMR $\left(101 \mathrm{MHz}, \mathrm{CD}_{2} \mathrm{Cl}_{2}\right)$ $\delta=151.63,144.83,142.34,141.37,141.00,140.68,137.70,136.37$, $135.70,135.53,135.49,135.17,133.65,131.13,130.20,127.79,127.77$, $127.42,126.70,125.69,124.27,122.23,35.44,34.75,34.51,31.82,0.12$ ppm. HRMS (MALDI TOF, DCTB): $\mathrm{m} / z$ calcd for $\mathrm{C}_{74} \mathrm{H}_{84} \mathrm{~S}_{6} \mathrm{Si}_{2}{ }^{+}\left[\mathrm{M}^{+}\right]$: 1220.4430, found: 1220.4422 .

4,16-Di-(3'-(3,5-di-tert-butylphenyl))-5''-iodo-[2,2':5',2"'-terthien]-5-yl-[2.2] paracyclophane 19: TMS-thienyl derivative 18 (752 mg, $620 \mu \mathrm{mol}, 1.00$ eq.) was dissolved in $\mathrm{CHCl}_{3}(50 \mathrm{~mL})$ and $\mathrm{AcOH}(50 \mathrm{~mL})$. After degassing the reaction mixture with argon, NIS $(314 \mathrm{mg}$, $1.35 \mathrm{mmol}, 2.20$ eq.) was added in one portion. It was stirred at room 
temperature for 1.5 hours and to the crude was added sat. aq. $\mathrm{NaHCO}_{3}$ The organic layer was washed with sat. aq. $\mathrm{NaHCO}_{3}$ and brine and was dried over $\mathrm{MgSO}_{4}$. The solvent was removed under reduced pressure and the crude was purified by column chromatography (cyclohexane $/ \mathrm{CH}_{2} \mathrm{Cl}_{2} 4: 1$ ) and 19 was obtained as a yellow wax $(812 \mathrm{mg}$ $610 \mu \mathrm{mol}, 99 \%) .{ }^{1} \mathrm{H}$ NMR $\left(500 \mathrm{MHz}, \mathrm{CD}_{2} \mathrm{Cl}_{2}\right) \delta=7.48\left(\mathrm{t},{ }^{4} \mathrm{~J}=1.8 \mathrm{~Hz}, 2 \mathrm{H}\right)$, $7.33\left(\mathrm{~d},{ }^{4} \mathrm{~J}=1.8 \mathrm{~Hz}, 4 \mathrm{H}\right), 7.23\left(\mathrm{~d},{ }^{3} \mathrm{~J}=3.7 \mathrm{~Hz}, 2 \mathrm{H}\right), 7.18(\mathrm{~s}, 2 \mathrm{H}), 7.03\left(\mathrm{~d},{ }^{3} \mathrm{~J}\right.$ $=3.7 \mathrm{~Hz}, 2 \mathrm{H}), 6.95\left(\mathrm{~d},{ }^{3} J=3.8 \mathrm{~Hz}, 2 \mathrm{H}\right), 6.92\left(\mathrm{~d},{ }^{3} J=3.8 \mathrm{~Hz}, 2 \mathrm{H}\right), 6.59(\mathrm{dd}$, ${ }^{3}$ J $=7.8 \mathrm{~Hz},{ }^{4}$ J $\left.=1.9 \mathrm{~Hz}, 2 \mathrm{H}\right), 6.49\left(\mathrm{~d},{ }^{4}\right.$ J $\left.=1.9 \mathrm{~Hz}, 2 \mathrm{H}\right), 6.41\left(\mathrm{~d},{ }^{3}\right.$ J $=7.8$ $\mathrm{Hz}, 2 \mathrm{H}), 3.66-3.61(\mathrm{~m}, 2 \mathrm{H}), 2.90-2.77(\mathrm{~m}, 6 \mathrm{H}), 1.35(\mathrm{~s}, 36 \mathrm{H}) \mathrm{ppm} .{ }^{13} \mathrm{C}$ NMR $\left(126 \mathrm{MHz}, \mathrm{CD}_{2} \mathrm{Cl}_{2}\right) \delta=151.10,144.46,142.86,140.74,140.09$, $138.00,137.12,135.47,134.91,134.90,134.53,133.57,133.07,131.12$, $129.64,127.62,127.01,126.13,125.21,123.67,121.76,72.07,34.86$, $34.16,33.92,31.24$ ppm. HRMS (MALDI TOF, DCTB): $\mathrm{m} / z$ calcd for $\mathrm{C}_{68} \mathrm{H}_{62} \mathrm{l}_{2} \mathrm{~S}_{6}{ }^{+}\left[M^{+}\right]: 1328.1573$, found: 1328.1570 .

\section{4,16-Di-(3',3'"'-bis(3,5-di-tert-butylphenyl))-[2,2':5',2":5",2"'"} quarterthien]-5-yl-[2.2] paracyclophane 20: Diiodo compound 19 $(800 \mathrm{mg}, 620 \mu \mathrm{mol}, 1.00 \mathrm{eq})$. boronic ester $7(982 \mathrm{mg}, 2.46 \mathrm{mmol}$ 4.00 eq.) and $\mathrm{K}_{2} \mathrm{CO}_{3}(511 \mathrm{mg}, 3.70 \mathrm{mmol}, 6.00$ eq.) were suspended in toluene $(30 \mathrm{~mL})$ and $\mathrm{MeOH}(30 \mathrm{~mL})$. The reaction mixture was degassed with argon and Pd-PEPPSI-IPr $(42.6 \mathrm{mg}, 61.6 \mu \mathrm{mol}$, $5 \mathrm{~mol} \%$ ) was added. The reaction mixture was placed in a preheated oil bath and the reaction was stirred at $70{ }^{\circ} \mathrm{C}$ for 30 minutes. The reaction was allowed to reach room temperature and the organic layer was washed with $2 \mathrm{M} \mathrm{HCl}$. It was dried over $\mathrm{MgSO}_{4}$ and the solvent was removed under reduced pressure. The crude was purified by column chromatography (cyclohexane/ $\mathrm{CH}_{2} \mathrm{Cl}_{2} 4: 1$ ) and $\mathbf{2 0}$ was obtained as a yellow wax (827 mg, $511 \mu \mathrm{mol}, 83 \%) .{ }^{1} \mathrm{H}$ NMR $\left(500 \mathrm{MHz}, \mathrm{CD}_{2} \mathrm{Cl}_{2}\right)$ $\delta=7.52(\mathrm{t}, 4 \mathrm{~J}=1.8 \mathrm{~Hz}, 2 \mathrm{H}), 7.48(\mathrm{t}, 4 \mathrm{~J}=1.8 \mathrm{~Hz}, 2 \mathrm{H}), 7.38-7.34(\mathrm{~m}$, $10 \mathrm{H}), 7.20\left(\mathrm{~d},{ }^{3} \mathrm{~J}=5.2 \mathrm{~Hz}, 2 \mathrm{H}\right), 7.12-7.10(\mathrm{~m}, 4 \mathrm{H}), 7.06\left(\mathrm{~d},{ }^{3} J=3.8 \mathrm{~Hz}\right.$ $2 \mathrm{H}), 7.04\left(\mathrm{~d},{ }^{3} \mathrm{~J}=3.8 \mathrm{~Hz}, 2 \mathrm{H}\right), 6.97\left(\mathrm{~d},{ }^{3} \mathrm{~J}=3.8 \mathrm{~Hz}, 2 \mathrm{H}\right), 6.65\left(\mathrm{dd},{ }^{3} \mathrm{~J}=7.8\right.$ $\left.\mathrm{Hz},{ }^{4} J=1.9 \mathrm{~Hz}, 2 \mathrm{H}\right), 6.54\left(\mathrm{~d},{ }^{4} J=1.9 \mathrm{~Hz}, 2 \mathrm{H}\right), 6.46\left(\mathrm{~d},{ }^{3} J=7.8 \mathrm{~Hz}, 2 \mathrm{H}\right)$, $3.67-3.62(\mathrm{~m}, 2 \mathrm{H}), 2.96-2.82(\mathrm{~m}, 6 \mathrm{H}), 1.39(\mathrm{~s}, 36 \mathrm{H}), 1.38(\mathrm{~s}, 36 \mathrm{H}) \mathrm{ppm}$. ${ }^{13} \mathrm{C}$ NMR $\left(126 \mathrm{MHz}, \mathrm{CD}_{2} \mathrm{Cl}_{2}\right) \delta=151.62,151.43,144.88,141.31,141.01$, $140.68,137.70,137.27,136.28,136.11,135.58,135.48,135.45,135.29$, $135.15,133.65,131.47,131.32,131.07,130.20,127.98,127.51,127.49$, $126.72,124.71,124.35,124.30,124.22,122.23,121.99,35.44,35.40$, $34.75,34.51,31.82,31.76$ ppm. HRMS (MALDI TOF, DCTB): $\mathrm{m} / \mathrm{z}$ calcd for $\mathrm{C}_{104} \mathrm{H}_{112} \mathrm{~S}_{8}{ }^{+}\left[M^{+}\right]: 1616.6524$, found: 1616.6526 .

\section{4,16-Di-(5"'-bromo-3',3"'-bis(3,5-di-tert-butylphenyl))-} $\left[2,2^{\prime}: 5^{\prime}, 2^{\prime \prime}: 5 ", 2^{\prime \prime \prime}\right.$ quarterthien]-5-yl-[2.2]paracyclophane Octathiophene $\mathbf{2 0}\left(385 \mathrm{mg} 240 \mathrm{\mu mol} 1.00 \mathrm{eq}\right.$ ) was dissolved in $\mathrm{CHCl}_{3}$ $(70 \mathrm{~mL})$ and to this was added in the dark NBS $(84.7 \mathrm{mg}, 480 \mu \mathrm{mol}$, 2.00 eq.). The reaction was stirred at room temperature for 20 hours. The organic layer was washed with $2 \mathrm{M} \mathrm{HCl}$ and was dried over $\mathrm{MgSO}_{4}$. The solvent was removed under reduced pressure and the crude product was purified by column chromatography $\left(\mathrm{CH}_{2} \mathrm{Cl}_{2} /\right.$ cyclohexane 1:9). 21 was isolated as a yellow wax (381 mg, $210 \mu \mathrm{mol}, 90 \%) .{ }^{1} \mathrm{H}$ NMR $\left(400 \mathrm{MHz}, \mathrm{CD}_{2} \mathrm{Cl}_{2}\right) \delta=7.46\left(\mathrm{t}_{1}{ }^{J} J=1.8 \mathrm{~Hz}, 2 \mathrm{H}\right), 7.43\left(\mathrm{t},{ }^{4} J=1.8 \mathrm{~Hz}, 2 \mathrm{H}\right)$ $7.30\left(\mathrm{~d},{ }^{4} \mathrm{~J}=1.8 \mathrm{~Hz}, 4 \mathrm{H}\right), 7.25\left(\mathrm{~d},{ }^{4} \mathrm{~J}=1.8 \mathrm{~Hz}, 4 \mathrm{H}\right), 7.12(\mathrm{~s}, 2 \mathrm{H}), 7.09-$ $7.08(\mathrm{~m}, 4 \mathrm{H}), 7.00\left(\mathrm{~d},{ }^{3} \mathrm{~J}=3.7 \mathrm{~Hz}, 2 \mathrm{H}\right), 6.96\left(\mathrm{~d},{ }^{3} \mathrm{~J}=3.8 \mathrm{~Hz}, 2 \mathrm{H}\right), 6.91(\mathrm{~d}$ $\left.{ }^{3} \mathrm{~J}=3.7 \mathrm{~Hz}, 2 \mathrm{H}\right), 6.58\left(\mathrm{dd},{ }^{3} \mathrm{~J}=7.8 \mathrm{~Hz},{ }^{4} J=1.9 \mathrm{~Hz}, 2 \mathrm{H}\right), 6.48\left(\mathrm{~d},{ }^{4} \mathrm{~J}=1.9\right.$ $\mathrm{Hz}, 2 \mathrm{H}), 6.40(\mathrm{~d}, 3 \mathrm{~J}=7.8 \mathrm{~Hz}, 2 \mathrm{H}), 3.66-3.60(\mathrm{~m}, 2 \mathrm{H}), 2.90-2.74(\mathrm{~m}$, $6 \mathrm{H}), 1.33(\mathrm{~s}, 36 \mathrm{H}), 1.31(\mathrm{~s}, 36 \mathrm{H}) \mathrm{ppm} .{ }^{13} \mathrm{C}$ NMR $\left(101 \mathrm{MHz}, \mathrm{CD}_{2} \mathrm{Cl}_{2}\right)$ $\delta=151.64,151.60,144.94,141.36,141.33,140.67,137.85,137.69$, $136.20,135.51,135.47,135.12,135.00,134.70,134.37,133.94,133.63$, $132.86,131.31,130.20,128.33,127.70,127.52,126.72,124.25,124.21$, 124.20, 122.42, 122.26, 111.30, 35.43, 35.41, 34.74, 34.50, 31.80, 31.71 ppm. HRMS (MALDI TOF, DCTB): $m / z$ calcd for $\mathrm{C}_{104} \mathrm{H}_{110} \mathrm{Br}_{2} \mathrm{~S}_{8}{ }^{+}\left[M^{+}\right]$: 1772.4734, found: 1772.4743 .

\section{4,16-Di-(3',3'"'-bis(3,5-di-tert-butylphenyl))-5'"'-trimethylsilyl-} [2,2':5',2":5", 2"'::5"',2'"''qinquethien]-5-yl-[2.2]paracyclophane 4: Dibromide 21 (160 mg, 90.0 umol, 1.00 eq), boronic ester 8 (153 mg, $540 \mu \mathrm{mol}, 6.00$ eq.) and $\mathrm{K}_{2} \mathrm{CO}_{3}(74.8 \mathrm{mg}, 540 \mu \mathrm{mol}, 6.00$ eq.) were suspended in toluene $(10 \mathrm{~mL})$ and $\mathrm{MeOH}(10 \mathrm{~mL})$. The reaction mixture was degassed with argon and Pd-PEPPSI-IPr ${ }^{\mathrm{TM}}(6.15 \mathrm{mg}$, $9.02 \mu \mathrm{mol}, 10 \mathrm{~mol} \%$ ) was added. The reaction mixture was placed in a preheated oil bath and the reaction was stirred at $70^{\circ} \mathrm{C}$ for 30 minutes.
The reaction was allowed to reach room temperature and the organic layer was washed with $2 \mathrm{M} \mathrm{HCl}$. It was dried over $\mathrm{MgSO}_{4}$ and the solvent was removed under reduced pressure. The crude was purified by column chromatography (cyclohexane $/ \mathrm{CH}_{2} \mathrm{Cl}_{2} 4: 1$ ) as well as GPC. 4 was obtained as a yellow wax (125 mg, $65.0 \mu \mathrm{mol}, 72 \%) .{ }^{1} \mathrm{H}$ NMR $(500$ $\left.\mathrm{MHz}, \mathrm{CD}_{2} \mathrm{Cl}_{2}\right) \delta=7.46\left(\mathrm{t},{ }^{4} J=1.8 \mathrm{~Hz}, 2 \mathrm{H}\right), 7.45\left(\mathrm{t},{ }^{4} J=1.8 \mathrm{~Hz}, 2 \mathrm{H}\right), 7.32$ - $7.30(\mathrm{~m}, 10 \mathrm{H}), 7.21(\mathrm{~s}, 2 \mathrm{H}), 7.20\left(\mathrm{~d},{ }^{3} J=3.5 \mathrm{~Hz}, 2 \mathrm{H}\right), 7.10-7.08(\mathrm{~m}$, $4 \mathrm{H}), 7.01-6.99(\mathrm{~m}, 4 \mathrm{H}), 6.92\left(\mathrm{~d},{ }^{3} \mathrm{~J}=3.7 \mathrm{~Hz}, 2 \mathrm{H}\right), 6.59\left(\mathrm{dd},{ }^{3} \mathrm{~J}=7.8 \mathrm{~Hz}\right.$, $\left.{ }^{4} J=1.9 \mathrm{~Hz}, 2 \mathrm{H}\right), 6.49\left(\mathrm{~d},{ }^{4} J=1.9 \mathrm{~Hz}, 2 \mathrm{H}\right), 6.41\left(\mathrm{~d},{ }^{3} \mathrm{~J}=7.8 \mathrm{~Hz}, 2 \mathrm{H}\right), 3.66$ - $3.61(\mathrm{~m}, 2 \mathrm{H}), 2.90-2.77(\mathrm{~m}, 6 \mathrm{H}), 1.34-1.33(\mathrm{~m}, 72 \mathrm{H}), 0.35(\mathrm{~s}, 18 \mathrm{H})$ ppm. ${ }^{13} \mathrm{C}$ NMR $\left(126 \mathrm{MHz}, \mathrm{CD}_{2} \mathrm{Cl}_{2}\right) \delta=151.61,151.56,142.16,142.15$, $141.59,141.58,141.31,141.14,140.67,137.69,137.22,137.21,136.25$, $135.82,135.74,135.53,135.52,135.46,135.22,135.12,133.63,130.40$, $130.19,127.83,127.71,127.51,127.49,126.71,125.80,124.29,124.28$, 124.20, 122.28, 122.23, 35.43, 35.42, 34.73, 34.49, 31.80, 31.75, 0.10 ppm. HRMS (MALDI TOF, DCTB): $m / z$ calcd for $\mathrm{C}_{118} \mathrm{H}_{132} \mathrm{~S}_{10} \mathrm{Si}_{2}{ }^{+}\left[\mathrm{M}^{+}\right]$: 1924.7069, found: 1924.7068 .

\section{4,16-Di-((3',3"'-bis(3,5-di-tert-butylphenyl))-5"'"-((4-} cyanopropyl)diisopropyl)silylethynyl-[2,2':5',2":5",,2"':5'", $2^{\prime \prime \prime \prime-~}$ qinquethien]-5-yl)-[2.2] paracyclophane 3: Decathiophene 4 (125 mg, $65.0 \mu \mathrm{mol}, 1.00$ eq.) was suspended in $\mathrm{CHCl}_{3}(5 \mathrm{~mL})$ and $\mathrm{AcOH}(5 \mathrm{~mL})$ and was degassed with argon. NBS $(24.3 \mathrm{mg}, 137 \mu \mathrm{mol}$, 2.10 eq.) was added in one portion and the reaction was stirred at room temperature for 15 minutes. The crude was poured into sat. aq. $\mathrm{NaHCO}_{3}$ and the organic layer was washed with brine. The solvent was removed under reduced pressure and the crude was passed through a plug of silica gel in toluene. After removal of the solvent, the crude was dissolved in toluene $(5 \mathrm{~mL})$ and diisopropylamine $(2 \mathrm{~mL})$. To this was added CPDIPS acetylene (27.3 mg, $131 \mu \mathrm{mol}, 3.00 \mathrm{eq}$.) and the mixture was degassed with argon. $\mathrm{Pd}\left(\mathrm{PPh}_{3}\right)_{4}(2.53 \mathrm{mg}, 2.20 \mu \mathrm{mol}$, $5.0 \mathrm{~mol} \%)$ and Cul $(0.21 \mathrm{mg}, 1.10 \mu \mathrm{mol}, 2.5 \mathrm{~mol} \%)$ were added to the reaction mixture and it was heated to $100{ }^{\circ} \mathrm{C}$ for 20 hours. After completion of the reaction, it was diluted with toluene, and the organic layer was washed with $2 \mathrm{M} \mathrm{HCl}$. It was dried over $\mathrm{MgSO}_{4}$ and the solvent was removed under reduced pressure. The crude was purified by column chromatography in toluene and $\mathbf{3}$ was obtained as an orange wax $(92.6 \mathrm{mg}, 43.8 \mu \mathrm{mol}, 63 \%) .{ }^{1} \mathrm{H}$ NMR $\left(400 \mathrm{MHz}, \mathrm{CD}_{2} \mathrm{Cl}_{2}\right)$ $\delta=7.48-7.46(\mathrm{~m}, 4 \mathrm{H}), 7.32\left(\mathrm{~d},{ }^{4} \mathrm{~J}=1.8 \mathrm{~Hz}, 8 \mathrm{H}\right), 7.22(\mathrm{~s}, 2 \mathrm{H}), 7.20\left(\mathrm{~d},{ }^{3} \mathrm{~J}\right.$ $=3.8 \mathrm{~Hz}, 2 \mathrm{H}), 7.12\left(\mathrm{~d},{ }^{3} \mathrm{~J}=3.8 \mathrm{~Hz}, 2 \mathrm{H}\right), 7.10-7.09(\mathrm{~m}, 4 \mathrm{H}), 7.02-7.00$ $(\mathrm{m}, 4 \mathrm{H}), 6.92\left(\mathrm{~d},{ }^{3} J=3.8 \mathrm{~Hz}, 2 \mathrm{H}\right), 6.60\left(\mathrm{dd},{ }^{3} J=7.8 \mathrm{~Hz},{ }^{4} J=1.9 \mathrm{~Hz}, 2 \mathrm{H}\right)$, $6.49\left(\mathrm{~d},{ }^{4} \mathrm{~J}=1.9 \mathrm{~Hz}, 2 \mathrm{H}\right), 6.41\left(\mathrm{~d},{ }^{3} \mathrm{~J}=7.8 \mathrm{~Hz}, 2 \mathrm{H}\right), 3.67-3.61(\mathrm{~m}, 2 \mathrm{H})$, $2.92-2.77(\mathrm{~m}, 6 \mathrm{H}), 2.44(\mathrm{t}, J=7.0 \mathrm{~Hz}, 4 \mathrm{H}), 1.91-1.81(\mathrm{~m}, 4 \mathrm{H}), 1.35(\mathrm{~s}$, $72 \mathrm{H}), 1.12-1.09(\mathrm{~m}, 24 \mathrm{H}), 0.89-0.83(\mathrm{~m}, 4 \mathrm{H})$. ppm. ${ }^{13} \mathrm{C}$ NMR $(101 \mathrm{MHz}$, $\left.\mathrm{CD}_{2} \mathrm{Cl}_{2}\right) \delta=151.66,151.64,144.94,141.66,141.35,140.68,138.95$, $137.70,137.54,136.23,135.54,135.49,135.43,135.14,135.02,134.75$, $134.41,133.65,131.36,131.24,130.21,128.47,127.94,127.61,127.53$, $126.73,124.30,124.21,124.16,122.50,122.44,122.265,122.258$, $120.30,100.36,96.66,35.46,35.44,34.75,34.51,31.82,31.77,30.28$, $21.86,21.27,18.55,18.32,12.32,10.15$ ppm. Two aliphatic carbon signals do not correspond to a signal from compound A. HRMS (MALDI TOF, DCTB): $m / z$ calcd for $\mathrm{C}_{136} \mathrm{H}_{154} \mathrm{~N}_{2} \mathrm{~S}_{10} \mathrm{Si}_{2}{ }^{+}\left[M^{+}\right]$: 2190.8852 , found: 2190.8816 .

\section{4,16-Di-((3',3'"'-bis(3,5-di-tert-butylphenyl))-5'"'-ethynyl-} $\left[2,2^{\prime}: 5^{\prime}, 2^{\prime \prime}: 5^{\prime \prime}, 2^{\prime \prime \prime}: 5\right.$ '", 2'"' qinquethien]-5-yl)-[2.2] paracyclophane 22: Compound 3 ( $150 \mathrm{mg}, 70.0 \mu \mathrm{mol}, 1.00$ eq.) was dissolved in wetted THF ( $25 \mathrm{~mL})$. The reaction mixture was degassed with argon and TBAF $(1.0 \mathrm{M}$ in THF, $0.21 \mathrm{~mL}, 210 \mu \mathrm{mol}, 3.00$ eq.) was added dropwise. The reaction was stirred at room temperature for 20 hours and the reaction mixture was diluted with toluene. The organic layer was washed with brine and dried over $\mathrm{MgSO}_{4}$. After column chromatography (cyclohexane $/ \mathrm{CH}_{2} \mathrm{Cl}_{2}$ 4:1), 22 was received as an orange wax (124 mg, $68.0 \mu \mathrm{mol}, 97 \%) .{ }^{1} \mathrm{H}$ NMR $\left(400 \mathrm{MHz}, \mathrm{CD}_{2} \mathrm{Cl}_{2}\right) \delta=7.47-7.45(\mathrm{~m}, 4 \mathrm{H})$, $7.31(\mathrm{~d}, J=1.8 \mathrm{~Hz}, 8 \mathrm{H}), 7.23\left(\mathrm{~d},{ }^{3} \mathrm{~J}=3.9 \mathrm{~Hz}, 2 \mathrm{H}\right), 7.22(\mathrm{~s}, 2 \mathrm{H}), 7.12\left(\mathrm{~d},{ }^{3} \mathrm{~J}\right.$ $=3.8 \mathrm{~Hz}, 2 \mathrm{H}), 7.10-7.08(\mathrm{~m}, 4 \mathrm{H}), 7.01-7.00(\mathrm{~m}, 4 \mathrm{H}), 6.92\left(\mathrm{~d},{ }^{3} \mathrm{~J}=3.8\right.$ $\mathrm{Hz}, 2 \mathrm{H}), 6.59\left(\mathrm{dd},{ }^{3} \mathrm{~J}=7.8 \mathrm{~Hz},{ }^{4} \mathrm{~J}=1.9 \mathrm{~Hz}, 2 \mathrm{H}\right), 6.49\left(\mathrm{~d},{ }^{4} \mathrm{~J}=1.9 \mathrm{~Hz}, 2 \mathrm{H}\right)$, $6.40\left(\mathrm{~d}^{3}{ }^{3} \mathrm{~J}=7.8 \mathrm{~Hz}, 2 \mathrm{H}\right), 3.66-3.60(\mathrm{~m}, 2 \mathrm{H}), 3.50(\mathrm{~s}, 2 \mathrm{H}), 2.91-2.76(\mathrm{~m}$, $6 \mathrm{H}), 1.35-1.33(\mathrm{~m}, 72 \mathrm{H}) \mathrm{ppm} .{ }^{13} \mathrm{C}$ NMR $\left(101 \mathrm{MHz}, \mathrm{CD}_{2} \mathrm{Cl}_{2}\right) \delta=151.47$, $151.45,144.74,141.98,141.45,140.48,138.96,137.50,137.35,136.03$, $135.33,135.21,134.93,134.81,134.55,134.39,133.44,133.07,131.25$, 
$131.04,130.03,128.37,128.33,127.74,127.42,127.33,126.53,124.09$, $124.00,123.91,122.25,122.06,121.19,120.85,82.83,76.95,35.25$, $35.24,34.55,34.31,31.61,31.56$ ppm. HRMS (MALDI TOF, DCTB): $\mathrm{m} / \mathrm{z}$ calcd for $\mathrm{C}_{116} \mathrm{H}_{116} \mathrm{~S}_{10}{ }^{+}\left[\mathrm{M}^{+}\right]$]: 1828.6279, found: 1828.6274 .

Macrocycle 23: Diyne 22 (60.0 mg, $32.8 \mu \mathrm{mol}, 1.00$ eq.) was dissolved in pyridine $(60 \mathrm{~mL})$ and degassed with argon. $\mathrm{CuCl}(48.7 \mathrm{mg}, 490 \mu \mathrm{mol}$, 15.0 eq.) and $\mathrm{Cu}(\mathrm{OAc})_{2}(125 \mathrm{mg}, 690 \mu \mathrm{mol}, 21.0 \mathrm{eq}$.) were dissolved in pyridine $(60 \mathrm{~mL})$ and degassed with argon. The solution of diyne 22 was added dropwise via syringe pump over the course of 48 hours. After completed addition, the crude was diluted with toluene, and $2 \mathrm{M}$ $\mathrm{HCl}$ was added. The organic layer was washed with $2 \mathrm{M} \mathrm{HCl}$ and brine and the solvent was removed under reduced pressure. The crude was filtered through a plug of celite and purified by size exclusion chromatography (BioBeads SX-3, toluene) and column chromatography (pentane $/ \mathrm{CH}_{2} \mathrm{Cl}_{2} 4: 1$ ). 23 was obtained as a red wax (19.8 mg, $10.8 \mu \mathrm{mol}, 33 \%) .{ }^{1} \mathrm{H}$ NMR $\left(600 \mathrm{MHz}, \mathrm{CD}_{2} \mathrm{Cl}_{2}\right) \delta=7.47-7.40$ $(\mathrm{m}, 4 \mathrm{H}), 7.40\left(\mathrm{~d},{ }^{4} \mathrm{~J}=1.8 \mathrm{~Hz}, 4 \mathrm{H}\right), 7.37\left(\mathrm{~d},{ }^{4} \mathrm{~J}=1.8 \mathrm{~Hz}, 4 \mathrm{H}\right), 7.29(\mathrm{~s}, 2 \mathrm{H})$, $7.25\left(\mathrm{~d},{ }^{3} \mathrm{~J}=3.8 \mathrm{~Hz}, 2 \mathrm{H}\right), 7.22-7.21(\mathrm{~m}, 4 \mathrm{H}), 7.05\left(\mathrm{~d},{ }^{3} \mathrm{~J}=3.8 \mathrm{~Hz}, 2 \mathrm{H}\right)$ $6.90\left(\mathrm{~d},{ }^{3} \mathrm{~J}=3.7 \mathrm{~Hz}, 2 \mathrm{H}\right), 6.76\left(\mathrm{~d},{ }^{3} \mathrm{~J}=3.7 \mathrm{~Hz}, 2 \mathrm{H}\right), 6.73-6.72(\mathrm{~m}, 2 \mathrm{H})$, $6.69-6.68(\mathrm{~m}, 4 \mathrm{H}), 6.66\left(\mathrm{~d},{ }^{3} J=3.9 \mathrm{~Hz}, 2 \mathrm{H}\right), 3.90-3.86(\mathrm{~m}, 2 \mathrm{H}), 3.04-$ $2.98(\mathrm{~m}, 6 \mathrm{H}), 1.36(\mathrm{~s}, 36 \mathrm{H}), 1.35(\mathrm{~s}, 36 \mathrm{H}) \mathrm{ppm} .{ }^{13} \mathrm{C} \mathrm{NMR}(151 \mathrm{MHz}$, $\left.\mathrm{CD}_{2} \mathrm{Cl}_{2}\right) \delta=151.66,151.50,143.75,141.07,141.03,140.82,140.52$, $136.89,136.26,135.68,135.65,135.48,135.40,134.78,134.75,134.16$, $134.13,133.05,131.66,131.14,129.99,129.98,128.18,126.91,126.47$, $126.27,125.24,123.87,123.77,123.69,123.07,122.16,121.98,121.01$ $80.05,78.62,35.29,35.28,34.93,34.85,31.59,31.58$ ppm. HRMS (MALDI TOF, DCTB): $\mathrm{m} / z$ calcd for $\mathrm{C}_{116} \mathrm{H}_{114} \mathrm{~S}_{10}{ }^{+}\left[\mathrm{M}^{+}\right]: 1826.6122$, found: 1826.6110 .

Macrocycle 1: Macrocycle 23 (4.00 mg, $2.19 \mu \mathrm{mol}, 1.00$ eq.) was suspended in DMF $(2 \mathrm{~mL})$ and 2-methoxyethanol $(2 \mathrm{~mL})$. It was degassed with argon and $\mathrm{Na}_{2} \mathrm{~S} \cdot 9 \mathrm{H}_{2} \mathrm{O}(5.26 \mathrm{mg}, 21.9 \mu \mathrm{mol}, 10.0$ eq.) was added to the reaction mixture. The reaction was placed in a preheated oil bath and was stirred for 1.5 hours at $120^{\circ} \mathrm{C}$. It was allowed to reach room temperature, diluted with toluene and washed with $2 \mathrm{M} \mathrm{HCl}$, repeatedly. The solvent was removed under reduced pressure and the crude was purified by column chromatography (pentane $\left./ \mathrm{CH}_{2} \mathrm{Cl}_{2} 4: 1\right) .1$ was obtained as a red wax $(4.00 \mathrm{mg}, 2.18 \mu \mathrm{mol}$, 99\%).

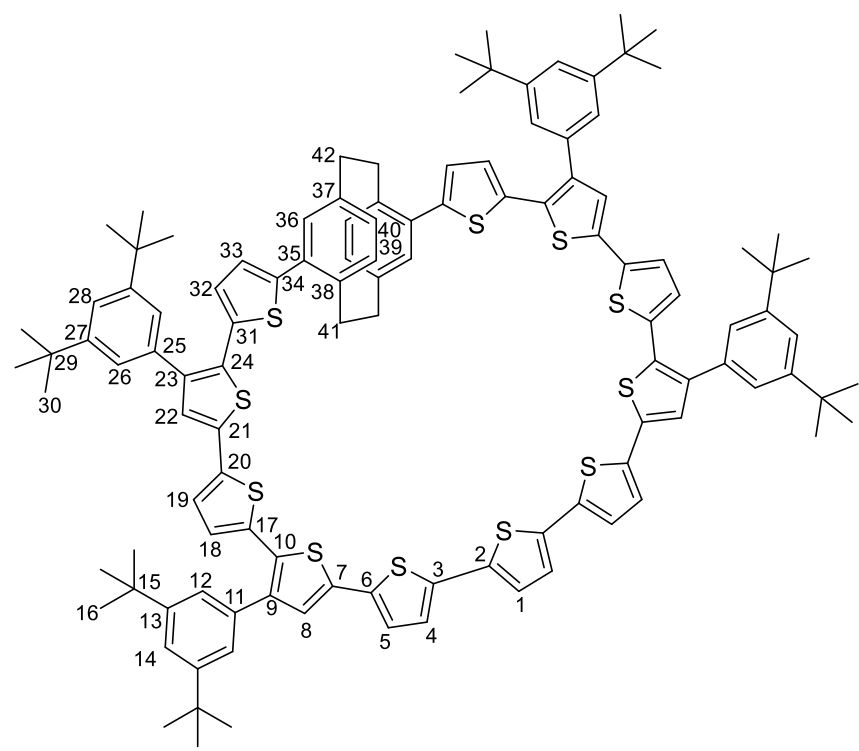

${ }^{1} \mathrm{H}$ NMR $\left(600 \mathrm{MHz}, \mathrm{CD}_{2} \mathrm{Cl}_{2}\right) \delta=7.47\left(\mathrm{t}^{4}{ }^{J}=1.9 \mathrm{~Hz}, 2 \mathrm{H}, \mathrm{H}-28 / \mathrm{H}-28 \mathrm{a}\right)$, $7.46\left(\mathrm{t},{ }^{4} \mathrm{~J}=1.8 \mathrm{~Hz}, 2 \mathrm{H}, \mathrm{H}-14 / \mathrm{H}-14 \mathrm{a}\right), 7.42\left(\mathrm{~d},{ }^{4} \mathrm{~J}=1.9 \mathrm{~Hz}, 4 \mathrm{H}, \mathrm{H}-26 / \mathrm{H}-\right.$ 26a), $7.37\left(\mathrm{~d},{ }^{4} \mathrm{~J}=1.8 \mathrm{~Hz}, 4 \mathrm{H}, \mathrm{H}-12 / \mathrm{H}-12 \mathrm{a}\right), 7.34-7.30(\mathrm{~m}, 8 \mathrm{H}, \mathrm{H}-1 / \mathrm{H}-$ 1a, H-4/H-4a, H-5/H-5a, H-8/H-8a), 7.21 (s, 2H, H-22/H-22a), 7.05 (d, $\left.{ }^{3} \mathrm{~J}=3.8 \mathrm{~Hz}, 2 \mathrm{H}, \mathrm{H}-19 / \mathrm{H}-19 \mathrm{a}\right), 6.90\left(\mathrm{~d},{ }^{3} \mathrm{~J}=3.7 \mathrm{~Hz}, 2 \mathrm{H}, \mathrm{H}-33 / \mathrm{H}-33 \mathrm{a}\right), 6.79$ $\left(\mathrm{d},{ }^{3} \mathrm{~J}=3.7 \mathrm{~Hz}, 2 \mathrm{H}, \mathrm{H}-32 / \mathrm{H}-32 \mathrm{a}\right), 6.76-6.72(\mathrm{~m}, 4 \mathrm{H}, \mathrm{H}-36 / \mathrm{H}-36 \mathrm{a}, \mathrm{H}-$ $39 / \mathrm{H}-39 a), 6.68\left(\mathrm{dd},{ }^{3} J=7.9 \mathrm{~Hz},{ }^{4} J=1.8 \mathrm{~Hz}, 2 \mathrm{H}, \mathrm{H}-40 / \mathrm{H}-40 \mathrm{a}\right), 6.62(\mathrm{~d}$, $3 \mathrm{~J}=3.9 \mathrm{~Hz}, 2 \mathrm{H}, \mathrm{H}-18 / \mathrm{H}-18 \mathrm{a}), 3.91-3.86(\mathrm{~m}, 2 \mathrm{H}, \mathrm{H}-41 / \mathrm{H}-41 \mathrm{a}), 3.03-$ $2.98(\mathrm{~m}, 2 \mathrm{H}, \mathrm{H}-41 / \mathrm{H}-41 \mathrm{a}), 2.92-2.88(\mathrm{~m}, 2 \mathrm{H}, \mathrm{H}-42 / \mathrm{H}-42 \mathrm{a}), 2.85-2.80$ $(\mathrm{m}, 2 \mathrm{H}, \mathrm{H}-42 / \mathrm{H}-42 \mathrm{a}), 1.37$ (s, 36H, H-30/H-30a), 1.35 (s, 36H, H-16/H16a) ppm. ${ }^{13} \mathrm{C}$ NMR (151 MHz, $\left.\mathrm{CD}_{2} \mathrm{Cl}_{2}\right) \delta=151.77$ (2 C, C-13/ C-13a), 151.64 (2 C, C-27/C-27a), 143.90 (2 C, C-34/C-34a), 143.75, (2 C, C37/C37a), 141.43 (2 C, C-9/C-9a), 140.47 (2 C, C-23/C-23a), 138.00 (2 C, C-38/C-38a), 137.19 (2 C, C-31/C-31a), 136.58 (2 C, C-2/C-2a), 136.55 (2 C, C-7/C-7a), 136.45 (2 C, C-3/C-3a), 136.23 (2 C, C-20/C-20a or C-21/C-21a), 135.88 (2 C, C-17/C-17a), 135.68 (2 C, C-24/C-24a), 135.54 (2 C, C-39/C-39a), 135.40 (2 C, C-11/C-11a), 135.16 (2 C, C-6/C6a), 135.15 (2 C, C-36/C-36a), 134.97 (2 C, C-20/C-20a or C-21/C-21a), 134.92 (2 C, C-35/C-35a), 131.14 (2 C, C-25/C-25a), 130.70 (2 C, C10/C-10a), 130.09 (2 C, C-40/C-40a), 128.02 (2 C, C-8/C-8a), 126.94 (2 C, C-22/C-22a), 126.79 (2 C, C-18/C-18a), 126.24 (2 C, C-33/C-33a), 125.18 (2 C, C-5/C-5a), 125.16 (2 C, C-1/C-1a), 125.01 (2 C, C-4/C-4a), 124.87 (2 C, C-32/C-32a), 124.03 (2 C, C-19/C-19a), 123.93 (2 C, C12/C-12a), 123.91 (2 C, C-26/C-26a), 122.17 (4 C, C-28/C-28a and C14/C-14a), 35.46 (2 C, C-29/C-29a), 35.43 (2 C, C-15/C-15a), 35.29 (2 C, C-41/C-41a), 35.16 (2 C, C-42/C-42a), 31.76 (2 C, C-30/C-30a), 31.75 (2 C, C-16/C-16a) ppm. HRMS (MALDI TOF, DCTB): $\mathrm{m} / \mathrm{z}$ calcd for $\mathrm{C}_{116} \mathrm{H}_{116} \mathrm{~S}_{11}{ }^{+}\left[M^{+}\right]$: 1860.5999 , found: 1860.5977 .

\section{Supplementary Material}

Supporting information for this article is available on the WWW under http://dx.doi.org/10.1002/MS-number.

\section{Acknowledgements}

We would like to thank the Mass Spectrometry team in the Molecular and Biomolecular Analysis service at ETH Zurich for their expert help in providing high-resolution measurements of the synthesized compounds. We acknowledge financial support by the European FP7-ITN MOLESCO (project no. 606728), the Swiss National Science Foundation (SNF, grant no. 200020-178808) and the Swiss Nanoscience Institute (SNI).

\section{Author Contribution Statement}

K. J. W. performed the synthesis and characterization of all materials and co-wrote the manuscript. D. H., N. M., and W. G. performed NMR analyses of the macrocyclic compounds. M. M. supervised the work and wrote the manuscript. All authors commented on the manuscript.

\section{References}

[1] J. D. Meindl, 'Limits on Silicon Nanoelectronics for Terascale Integration', Science 2001, 293, 2044-2049.

[2] S. Höger, 'Shape-Persistent Macrocycles: From Molecules to Materials', Chem. - Eur. J. 2004, 10, 1320-1329.

[3] J. Krömer, I. Rios-Carreras, G. Fuhrmann, C. Musch, M. Wunderlin, T. Debaerdemaeker, E. Mena-Osteritz, P. Bäuerle, 'Synthesis of the First Fully $\alpha$-Conjugated Macrocyclic Oligothiophenes: Cyclo[n]Thiophenes with Tunable Cavities in the Nanometer Regime', Angew. Chem. Int. Ed. 2000, 39, 3481-3486.

[4] L. Favereau, A. Cnossen, J. B. Kelber, J. Q. Gong, R. M. Oetterli, J. Cremers, L. M. Herz, H. L. Anderson, 'Six-Coordinate Zinc Porphyrins for TemplateDirected Synthesis of Spiro-Fused Nanorings', J. Am. Chem. Soc. 2015, 137, 14256-14259.

[5] M. S. Inkpen, S. Scheerer, M. Linseis, A. J. P. White, R. F. Winter, T. Albrecht, N. J. Long, ,Oligomeric Ferrocene Rings', Nat. Chem. 2016, 8, 825-830.

[6] H. Shimizu, J. D. Cojal González, M. Hasegawa, T. Nishinaga, T. Haque, M. Takase, H. Otani, J. P. Rabe, M. lyoda, 'Synthesis, Structures, and Photophysical Properties of $\pi$-Expanded Oligothiophene 8-Mers and Their Saturn-Like $C_{60}$ Complexes', J. Am. Chem. Soc. 2015, 137, 3877-3885. 
[7] E. A. Meyer, R. K. Castellano, F. Diederich, 'Interactions with Aromatic Rings in Chemical and Biological Recognition', Angew. Chem. Int. Ed. 2003 42, 1210-1250.

[8] H. A. Staab, F. Diederich, 'Cycloarenes, a New Class of Aromatic Compounds, I. Synthesis of Kekulene', Chem. Ber. 1983, 116, 3487-3503.

[9] C. Krieger, F. Diederich, D. Schweitzer, H. A. Staab, ,Molecular Structure and Spectroscopic Properties of Kekulene', Angew. Chem. Int. Ed. Engl. 1979, 18, 699-701.

[10] H. Omachi, Y. Segawa, K. Itami, 'Synthesis of Cycloparaphenylenes and Related Carbon Nanorings: A Step toward the Controlled Synthesis of Carbon Nanotubes', Acc. Chem. Res. 2012, 45, 1378-1389.

[11] M. Iyoda, J. Yamakawa, M. J. Rahman, 'Conjugated Macrocycles: Concepts and Applications', Angew. Chem. Int. Ed. 2011, 50, 10522-10553.

[12] V. Hoffmann, L. le Pleux, D. Häussinger, O. T. Unke, A. Prescimone, M. Mayor, 'Deltoid versus Rhomboid: Controlling the Shape of Bis-Ferrocene Macrocycles by the Bulkiness of the Substituents', Organometallics 2017, 36, 858-866.

[13] M. Mayor, J.-M. Lehn, 'Reducible Nanosize Macrocycles', J. Am. Chem. Soc. 1999, 121, 11231-11232.

[14] M. Müri, K. C. Schuermann, L. De Cola, M. Mayor, 'Shape-Switchable AzoMacrocycles', Eur. J. Org. Chem. 2009, 15, 2562-2575.

[15] A. Błaszczyk, M. Chadim, C. von Hänisch, M. Mayor, 'Synthesis of Macrocyclic Molecular Rods as Potential Electronic Devices', Eur. J. Org. Chem. 2006, 17, 3809-3825.

[16] N. Weibel, A. Mishchenko, T. Wandlowski, M. Neuburger, Y. Leroux, M. Mayor, 'Catechol-Based Macrocyclic Rods: En Route to Redox-Active Molecular Switches', Eur. J. Org. Chem. 2009, 35, 6140-6150.

[17] L. Le Pleux, E. Kapatsina, J. Hildesheim, D. Häussinger, M. Mayor, 'A Molecular Turnstile as an E-Field-Triggered Single-Molecule Switch: Concept and Synthesis', Eur. J. Org. Chem. 2017, 22, 3165-3178.

[18] L. Shu, M. Mayor, 'Shape-Persistent Macrocycle with a SelfComplementary Recognition Pattern Based on Diacetylene-Linked Alternating Hexylbenzene and Perfluorobenzene Rings', Chem. Commun. 2006, 4134-4136.

[19] L. Shu, M. Müri, R. Krupke, M. Mayor, 'Shape-Persistent Macrocycles Comprising Perfluorinated Benzene Subunits: Synthesis, Aggregation Behaviour and Unexpected $\mu$-Rod Formation', Org. Biomol. Chem. 2009 7, 1081.

[20] M. Mayor, C. Didschies, 'A Giant Conjugated Molecular Ring', Angew. Chem. Int. Ed. 2003, 42, 3176-3179.

[21] R. Mannancherry, M. Rickhaus, D. Häussinger, A. Prescimone, M. Mayor, 'Molecular Dynamic Staircases: All-Carbon Axial Chiral "Geländer" Structures', Chem. Sci. 2018, 9, 5758-5766.

[22] T. Brandl, V. Hoffmann, A. Pannwitz, D. Häussinger, M. Neuburger, O. Fuhr, S. Bernhard, O. S. Wenger, M. Mayor, ,Chiral Macrocyclic Terpyridine Complexes', Chem. Sci. 2018, 9, 3837-3843.

[23] M. Iyoda, H. Shimizu, 'Multifunctional $\pi$-Expanded Oligothiophene Macrocycles', Chem. Soc. Rev. 2015, 44, 6411-6424.

[24] P. Bäuerle, M. Ammann, M. Wilde, G. Götz, E. Mena-Osteritz, A. Rang, C. A. Schalley, 'Oligothiophene-Based Catenanes: Synthesis and Electronic Properties of a Novel Conjugated Topological Structure', Angew. Chem. Int. Ed. 2007, 46, 363-368.

[25] G. Götz, X. Zhu, A. Mishra, J.-L. Segura, E. Mena-Osteritz, P. Bäuerle, ' $\pi$ Conjugated [2]Catenanes Based on Oligothiophenes and Phenanthrolines: Efficient Synthesis and Electronic Properties', Chem. Eur. J. 2015, 21, 7193-7210.

[26] R. A. Shelby, 'Experimental Verification of a Negative Index of Refraction', Science 2001, 292, 77-79.

[27] Y. Shen, H.-Y. Ko, Q. Ai, S.-M. Peng, B.-Y. Jin, 'Molecular Split-Ring Resonators Based on Metal String Complexes', J. Phys. Chem. C 2014, 118, 3766-3773.

[28] M. W. Klein, C. Enkrich, M. Wegener, C. M. Soukoulis, S. Linden, 'SingleSlit Split-Ring Resonators at Optical Frequencies: Limits of Size Scaling', Opt. Lett. 2006, 31, 1259-1261.

[29] Y. Morisaki, M. Gon, T. Sasamori, N. Tokitoh, Y. Chujo, 'Planar Chiral Tetrasubstituted [2.2]Paracyclophane: Optical Resolution and Functionalization', J. Am. Chem. Soc. 2014, 136, 3350-3353.
[30] C. J. Brown, A. C. Farthing, 'Preparation and Structure of Di-p-Xylylene', Nature 1949, 164, 915-916.

[31] M. Gon, Y. Morisaki, Y. Chujo, 'Optically Active Cyclic Compounds Based on Planar Chiral [2.2]Paracyclophane: Extension of the Conjugated Systems and Chiroptical Properties', J. Mater. Chem. C 2015, 3, 521-529.

[32] D. S. Seferos, S. A. Trammell, G. C. Bazan, J. G. Kushmerick, 'Probing $\pi-$ Coupling in Molecular Junctions', Proc. Natl. Acad. Sci. 2005, 102, 88218825

[33] M. Wielopolski, A. Molina-Ontoria, C. Schubert, J. T. Margraf, E. Krokos, J. Kirschner, A. Gouloumis, T. Clark, D. M. Guldi, N. Martín, 'Blending Through-Space and Through-Bond $\pi-\pi$-Coupling in $\left[2,2^{\prime}\right]-$ Paracyclophane-Oligophenylenevinylene Molecular Wires', J. Am. Chem. Soc. 2013, 135, 10372-10381.

[34] J. L. Zafra, A. Molina Ontoria, P. Mayorga Burrezo, M. Peña-Alvarez, M. Samoc, J. Szeremeta, F. J. Ramírez, M. D. Lovander, C. J. Droske, T. M. Pappenfus, L. Echegoyen, J. T. López Navarrete, N. Martin, J. Casado, 'Fingerprints of Through-Bond and Through-Space Exciton and Charge $\pi$ Electron Delocalization in Linearly Extended [2.2]Paracyclophanes', J. Am. Chem. Soc. 2017, 139, 3095-3105.

[35] H. Hinrichs, A. J. Boydston, P. G. Jones, K. Hess, R. Herges, M. M. Haley, H. Hopf, 'Phane Properties of [2.2]Paracyclophane/Dehydrobenzoannulene Hybrids', Chem. - Eur. J. 2006, 12, 7103-7115.

[36] F. Salhi, B. Lee, C. Metz, L. A. Bottomley, D. M. Collard, 'Influence of $\pi-$ Stacking on the Redox Properties of Oligothiophenes: ( $\alpha$-AlkyloligoThienyl)Para[2.2]Cyclophanes', Org. Lett. 2002, 4, 3195-3198.

[37] D. Stefani, K. J. Weiland, M. Skripnik, C. Hsu, M. L. Perrin, M. Mayor, F. Pauly, H. S. J. van der Zant, 'Large Conductance Variations in a Mechanosensitive Single-Molecule Junction', Nano Lett. 2018, DOI 10.1021/acs.nanolett.8b02810.

[38] H. J. Reich, D. J. Cram, 'Macro Rings. XXXVII. Multiple Electrophilic Substitution Reactions of [2.2]Paracyclophanes and Interconversions of Polysubstituted Derivatives', J. Am. Chem. Soc. 1969, 91, 3527-3533.

[39] L. Bondarenko, I. Dix, H. Hinrichs, H. Hopf, 'Cyclophanes. Part LIl:Ethynyl[2.2]paracyclophanes - New Building Blocks for Molecular Scaffolding', Synthesis 2004, 16, 2751-2759.

[40] G. Meyer-Eppler, R. Sure, A. Schneider, G. Schnakenburg, S. Grimme, A. 'Lützen, Synthesis, Chiral Resolution, and Absolute Configuration of Dissymmetric 4,15-Difunctionalized [2.2]Paracyclophanes', J. Org. Chem. 2014, 79, 6679-6687.

[41] M. Hasegawa, K. Kobayakawa, H. Matsuzawa, T. Nishinaga, T. Hirose, K. Sako, Y. Mazaki, 'Macrocyclic Oligothiophene with Stereogenic [2.2]Paracyclophane Scaffolds: Chiroptical Properties from $\pi$ Transannular Interactions', Chem. - Eur. J. 2017, 23, 3267-3271.

[42] E. Flapan, 'When Topology Meets Chemistry: A Topological Look at Molecular Chirality', Cambridge University Press; Mathematical Association Of America, Cambridge; New York: Washington, DC, 2000.

[43] J.-C. Chambron, J.-P. Sauvage, K. Mislow, A. De Cian, J. Fischer, 'A [2]Catenane and a [2]Rotaxane as Prototypes of Topological and Euclidean Molecular "Rubber Gloves."', Chem. - Eur. J. 2001, 7, 4085-4096.

[44] P. Siemsen, R. C. Livingston, F. Diederich, 'Acetylenic Coupling: A Powerful Tool in Molecular Construction', Angew. Chem. Int. Ed. 2000, 39, 26322657.

[45] S. Odermatt, J. L. Alonso-Gómez, P. Seiler, M. M. Cid, F. Diederich, 'ShapePersistent Chiral Alleno-Acetylenic Macrocycles and Cyclophanes by Acetylenic Scaffolding with 1,3-Diethynylallenes', Angew. Chem. Int. Ed. 2005, 44, 5074-5078.

[46] J. L. Alonso-Gómez, P. Rivera-Fuentes, N. Harada, N. Berova, F. Diederich, 'An Enantiomerically Pure Alleno-Acetylenic Macrocycle: Synthesis and Rationalization of Its Outstanding Chiroptical Response', Angew. Chem. Int. Ed. 2009, 48, 5545-5548.

[47] Y. Wang, J. Song, L. Xu, Y. Kan, J. Shi, H. Wang, 'Synthesis and Characterization of Cyclooctatetrathiophenes with Different Connection Sequences', J. Org. Chem. 2014, 79, 2255-2262.

[48] D. Thirion, C. Poriel, R. Métivier, J. Rault-Berthelot, F. Barrière, O. Jeannin, 'Violet-to-Blue Tunable Emission of Aryl-Substituted DispirofluoreneIndenofluorene Isomers by Conformationally-Controllable Intramolecular Excimer Formation', Chem. - Eur. J. 2011, 17, 10272-10287. 


\section{HELVETICA}

[49] V. I. Rozenberg, E. V. Sergeeva, V. G. Kharitonov, N. V. Vorontsova, E. V. Vorontsov, V. V. Mikul'shina, 'Synthesis of Novel Mono- and DiarylSubstituted [2.2]Paracyclophanes', Russ. Chem. Bull. 1994, 43, 1018-1023.

[50] T. Klingstedt, A. Åslund, R. A. Simon, L. B. G. Johansson, J. J. Mason, S. Nyström, P. Hammarström, K. P. R. Nilsson, Org. Biomol. Chem. 2011, 9, 8356.

[51] G. Gaefke, S. Höger, '[(3-Cyanopropyl)Diisopropylsilyl]Acetylene, a More Stable Analogue of [(3-Cyanopropyl)Dimethylsilyl]Acetylene', Synthesis 2008, 14, 2155-2157.

[52] L. T. Scott, M. J. Cooney, C. Otte, C. Puls, T. Haumann, R. Boese, A. B. Smith, P. J. Carroll, A. de Meijere, 'Enhancement of Through-Space and ThroughBond .Pi.-Orbital Interactions. Syntheses and Properties of Permethylated and Perspirocyclopropanated Cyclotetradeca-1,3,6,9,12-Pentayne', J. Am. Chem. Soc. 1994, 116, 10275-10283.

[53] M. Rickhaus, M. Mayor, M. Juríček, 'Strain-Induced Helical Chirality in Polyaromatic Systems', Chem. Soc. Rev. 2016, 45, 1542-1556.

[54] M. Rickhaus, M. Mayor, M. Juríček, 'Chirality in Curved Polyaromatic Systems', Chem. Soc. Rev. 2017, 46, 1643-1660.

[55] M. Stępień, I. Simkowa, L. Latos - Grażyński, 'Helical Porphyrinoids: Incorporation of Ferrocene Subunits into Macrocyclic Structures', Eur. J. Org. Chem. 2008, 15, 2601-2611.

[56] M. Bednarz, P. Reineker, E. Mena-Osteritz, P. Bäuerle, 'Optical Absorption Spectra of Linear and Cyclic Thiophenes-Selection Rules Manifestation', J. Lumin. 2004, 110, 225-231.

[57] N. V. Vorontsova, V. I. Rozenberg, E. V. Sergeeva, E. V. Vorontsov, Z. A. Starikova, K. A. Lyssenko, H. Hopf, 'Symmetrically Tetrasubstituted [2.2]Paracyclophanes: Their Systematization and Regioselective Synthesis of Several Types of Bis-Bifunctional Derivatives by Double Electrophilic Substitution', Chem. - Eur. J. 2008, 14, 4600-4617. 


\section{Entry for the Table of Contents}

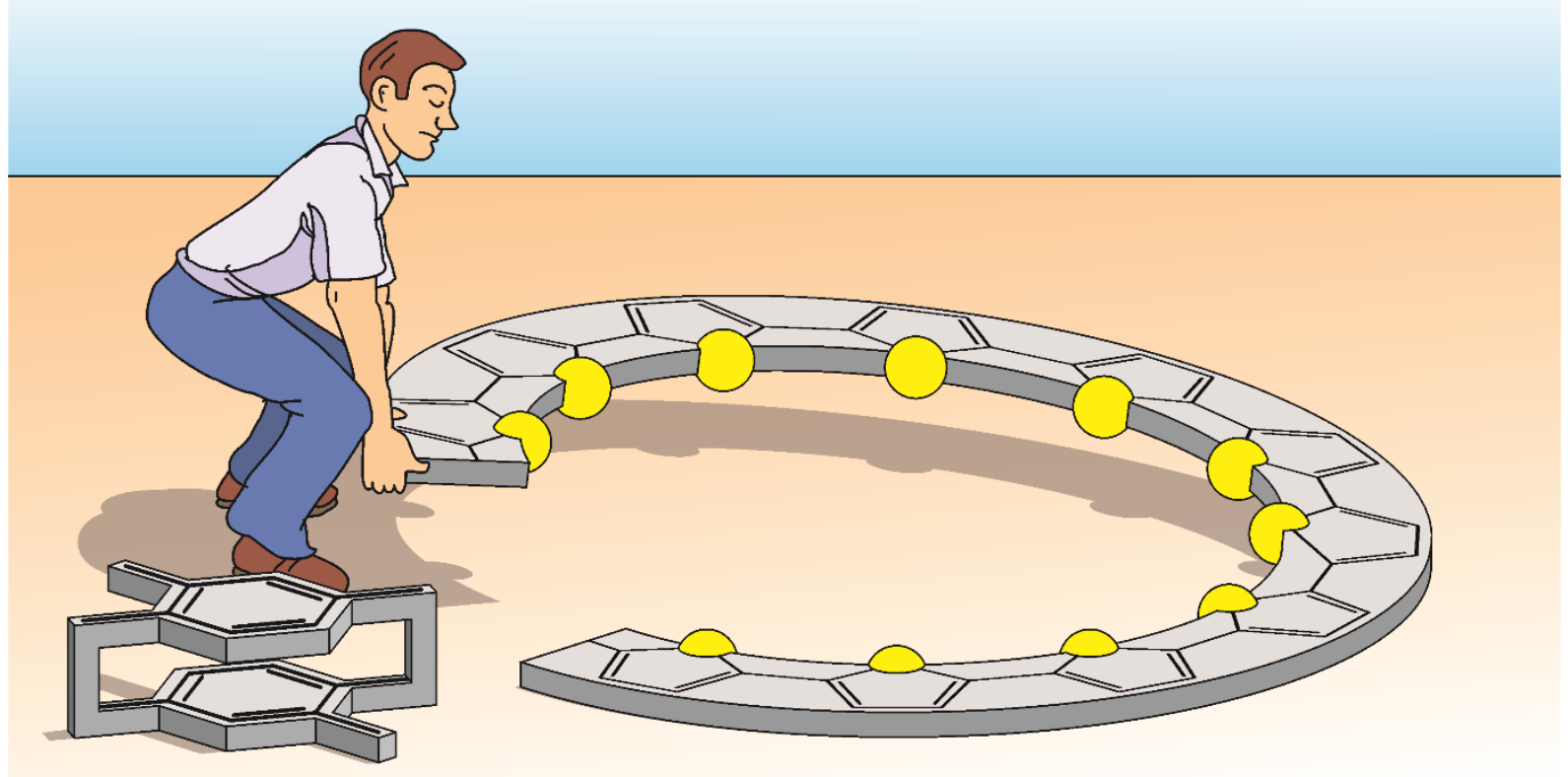

